\title{
A Fair Price for Energy? Ownership versus Market Opening in the EU15
}

\author{
Carlo V. Fiorio \\ Massimo Florio
}

CESIFO WORKING PAPER NO. 3124

CATEgory 1: Public Finance

JULY 2010
An electronic version of the paper may be downloaded
- from the SSRN website:
- from the RePEc website:
www.SSRN.com
Www.RePEc.org
- from the CESifo website:
www.CESifo-group.org/wp




\title{
A Fair Price for Energy? Ownership versus Market Opening in the EU15
}

\begin{abstract}
In the past two decades privatisation and liberalisation of network industries providing services of general economic interest (SGEI), have been particularly significant in the European Union. Wide variations around a common policy trend can, however, be observed across countries and sectors. We focus on electricity and gas sectors because energy sectors have usually been profit makers, not affected by direct government transfers, in contrast to other SGEI. We study the effects of privatisation and other reforms on consumer prices using both subjective data on consumers' perception of utility prices and data on average prices paid.
\end{abstract}

JEL-Code: L94, L95, L33.

Keywords: privatisation, electricity, gas, reforms.

Carlo V. Fiorio

Department of Economics, Business and

Statistics

University of Milan

Via Conservatorio, 7

20122 Milan

Italy

carlo.fiorio@unimi.it
Massimo Florio

Department of Economics, Business and

Statistics

University of Milan

Via Conservatorio, 7

20122 Milan

Italy

massimo.florio@unimi.it 


\section{INTRODUCTION}

In the past two decades privatisation and liberalisation of network industries providing services of general economic interest, such as electricity, gas, fixed and mobile telephony, water, and railways, have been particularly significant in the European Union. The key feature of these industries is that they include both a major fixed-cost component, the network, under increasing returns to scale, and several potentially competitive upstream or downstream operations. This feature leads often to natural monopoly for the network services, and potential market dominance of the vertically integrated network owner. Before the 1970s wide disappointment with earlier private monopolies or oligopolies, sheltered by various forms of long-term concessions, led most European governments to take control of industries often plagued by collusion, underinvestment and price discrimination. Millward (2005) offers a masterly account of the often more pragmatic than political reasons behind nationalisation and consolidation of energy industries in Europe in the last century.

In the 1970s, however, there was a dramatic policy reversal. In the mid-1980s the United Kingdom was the front-runner of reform, while, among the EU Member States, France has often been regarded as a country averse to moving away from public monopoly. In fact, in the last 15-20 years virtually all European countries have undertaken dramatic regulatory reforms in the network industries. Wide variations around a common policy trend can, however, be observed across countries and sectors, allowing us to assess the effects of the policy reform, and to study its effects on users.

A typical 'European-style’ reform package has four main dimensions: divestiture of public ownership; unbundling of the network from service operations; price regulation by an independent office (usually in the form of price capping); lifting of restrictions to market entry and finally full liberalisation. According to some early views, price controls had to be considered as a transitory mechanism to protect the consumer before full liberalisation, so that only generic anti-trust vigilance was needed at the end of the process (see e.g. Newbery and Pollitt, 1997; Newbery, 2000; Pollitt, 2007). 
In general, the EU institutions have been strongly supportive of the reforms, which are more advanced than in other regions. While neutral on public ownership divestiture, over the years the European Commission has proposed a number of important directives on energy sectors that push the Member States towards a homogenous pattern of regulatory legislation (see e.g. CEC, 2007). A new paradigm has emerged, and legislation is shaped by it across Europe. We want to test the paradigm on empirical grounds, disentangling the effect of privatisation from that of other reforms.

In this paper, we consider EU15 only, because data for the New Member States are less reliable, the time series are shorter, and privatisation and regulatory change from former planned economies is less comparable with change in industrial organisation elsewhere. We also limit our analysis to two energy industries (electricity, gas), each representing different stages and features of the reform story. This is a subset of all the network industries, but the core ones for most consumers. Moreover, government-owned providers in energy were not loss makers, their prices covered costs, and comparison with pricing of private firms is more meaningful than in other sectors.

As a first preliminary empirical exercise we analyse subjective data on perceived fairness of energy prices, using data from four Eurobarometer surveys collected between 2000 and 2006 and contrast them with trends of reforms as measured in a separate data set, the Indicators of Regulation in Energy, Transport and Communications (ETCR, and formerly known as REGREF), recently released by the OECD. Previous empirical research shows that it is unlikely that there is a positive net benefit of a policy reform if consumers do not get a fair dividend from it, see e.g. Ugaz and Waddams Price (2003). Moreover, if consumers do not perceive any net benefit, at a certain stage they can shift from indifference to opposition, as happened with similar reforms in Latin America, see e.g. Checchi et al. (2009). A simple inspection of the Eurobarometer surveys suggests that decreasing consumers' dissatisfaction might be correlated with more reforms. However, once we control for individual and for country-level characteristics, the latter including indicators of the reform, we find some interesting results, namely that the likelihood of consumers' 
dissatisfaction with the price they pay is consistently lower in countries where the ownership of the energy industries is public.

Although informative and relevant from a political economy point of view, correlations between consumers' preferences and reforms might be flawed by measurement errors or subject to various individual biases. We only take them as motivating evidence for analysing the issue further. As there is no comparable information on the prices paid by individual households in Europe, in this paper we focus on a long panel of actual average prices paid in the EU15.

A similar approach was followed for testing the impact of reforms by other authors, focussing however on variables other than prices. For example, Azmat et al. (2007) use REGREF variables to test the impact of privatisation and market liberalisation on employment and wages in several network industries in the OECD. Alesina et al. (2005) also use REGREF data for OECD countries to study product market regulation and investment. Nicoletti and Scarpetta (2003) use REGREF to study privatisation, liberalisation and productivity growth patterns across countries, particularly between continental Europe, the US and the UK.

Our main research question is: Are consumer prices of electricity and gas lower (after controlling for country and industry specific factors) in countries that implemented privatisation and liberalisation reforms? We are also interested to see whether consumers' perceptions of price fairness are correlated to actual prices.

The structure of the paper is the following: first, we briefly review some key facts about the reform and price trends in the European industries under consideration (Section 2). Then we look at the correlations between individual dissatisfaction of consumers with the price they pay for energy services and reform variables (Section 3). Earlier literature is briefly discussed in Section 4. Then we present our empirical modelling strategy (Section 5), the data we use (Section 6), and our results (Section 7). In Section 8, we discuss our findings and conclude offering some policy implications.

\section{REFORM AND ENERGY PRICE TRENDS}

The typical network industries reform package is characterised by privatisation, unbundling, and market opening. In the last two decades the EU has witnessed a 
considerable variability of policy combinations thereof. Thus we want to test separately the effects of privatisation and of the other two reforms.

Our research strategy is to focus on the energy industries because they cover different technological and institutional features. Electricity is a sector where the reforms started in the 1990s, with persistent differences in technologies and in the endowment of fuel resources across countries, while gas is a late-comer in the reform. The technology is similar across countries, but there are variations in dependency on a homogenous natural resource.

Public enterprises in these two sectors were (or are) profit-makers in Western Europe, and usually had no difficulty in financing their investments, hence their pricing is usually not affected by government transfers, as in other network industries (e.g. railways).

For each of these sectors the regulatory history has been summarised in the Indicators of Regulation in Energy, Transport and Communications (ETCR), recently (April 2009) released by the OECD and covering years 1975-2007 (Conway and Nicoletti, 2006). ETCR database provides an industry measure that comes from the aggregation of different dimensions of the reforms, such as public ownership, vertical integration, market entry, which themselves come as an aggregation of further decomposition of each regulatory dimension. All these indices score from 0 to 6, under different headings and sub-headings. An industry characterised by full public ownership, vertical integration, no access to the industry except for the public operator scores 6 in the aggregated indicator, which comes as the average of the maximum score reached in all subindicators. At the other extreme, an industry that is operated by private operators only, with total unbundling of its production process and full market opening will score 0 , the minimum.

Figure 1 presents the history of regulatory reform in a concise way, where trends are reported for the average of the overall and public ownership ETCR indicator, for each energy industry. The downward trend of the public ownership and overall ETCR index emerges, with the latter being more pronounced than the former, meaning that other dimensions of the reform (namely, entry liberalisation and unbundling) had an even more pronounced decreasing dynamics. The electricity industry reform starting date was around late 1980s: while unbundling and entry 
regulation were forced by EU legislation, it is interesting to notice that public ownership decreasing trend was particularly relevant since the end of the 1990s. Market structure in electricity is not reported in ETCR, but there is evidence elsewhere (CEC 2007) of a tendency towards oligopoly with a competitive fringe (Helm, 2003). In the gas sector the overall process of liberalisation and divestiture of public ownership is less pronounced, although the average indicator of public ownership decreased one point from an initial average of five. In fact, after a start-up in the mid-1980s, privatisation proceeded very slowly and has stopped in several countries in recent years.

How did consumer prices evolve since the end of 1970s? Figure 1 also depicts the median price of each SGEI across the EU15, using the longest times series available of average national prices, deflated using the yearly national consumer price index and setting at 100 the median price in 1978 (more details on the price data used will be provided in Section 6). The first panel shows the clear downward trend of electricity prices during the 1980s and the 1990s although the trend was partly the opposite before and after this period. It is however worth noting that the downward price trend started well before the reform wave showed its first signs: about half the average price reduction happened before 1990, when the reforms started in the UK (the front runner of reforms in the EU15). Another third happened before 1996, when the first EU Directive was approved. After 2003, when the second EU directive was approved, the price started increasing, most likely due to the increasing cost of oil, a relevant input in energy production. The correlation between prices and reforms is even less clear in the gas industry (second panel): prices increased up to early 1980s, while no reform had started. Major price reductions took place between 1985 and 2000, while the ETCR index had barely reduced and in the following years the two series present a negative correlation.

\section{[Figure 1 about here]}

It is also informative to look at price figures deflated using the consumer price index for some relevant years in two key countries, the UK and France often regarded as at the two extremes of reform policy implementation (Table 1). In 1978 the standard deviation of electricity prices in the EU was wide, about as large as its average and prices paid in France and in the UK are equal and well below the EU15 
mean. Since 1990 up until the end of the period considered, French prices tend to be lower and UK ones higher than the average, besides the convergence of prices across the EU15 as showed by the decreasing standard deviation. In 1978 French gas prices where about $50 \%$ higher than the UK prices, which were close to the EU average level. After thirty years gas prices for these two countries converged close to the average.

The message from this example is twofold: first, relative prices show strong and different dynamics across countries; second, to study the impact of privatisation and liberalisation we need to control for possible cost and demand shifters across sectors, as the simple correlation between prices and reform trends is weak.

[Table 1 about here]

\section{EVIDENCE ON SUBJECTIVE PERCEPTION OF PRICE FAIRNESS}

In this section we briefly present the data used for the analysis of consumers' perceptions and main results. The objective of this preliminary analysis is to show that there may be some dissatisfaction in Europe with the outcome of energy reforms. ${ }^{1}$

\subsection{The data used for the analysis of consumers' perceptions}

For analysing consumer perceptions on prices, we used self-rated dissatisfaction with the prices paid for each service considered (electricity and gas) by a representative sample of EU15 citizens, as measured in the Eurobarometer (2002, 2004, 2006, 2008) surveys (henceforth EB), which were run biannually between 2000 and 2008. Although formulated in a very generic way, ${ }^{2}$ the question of price satisfaction was checked for consistency with the prices paid by an average consumer. The EB data also include a large list of individual characteristics, allowing us to control for some individual heterogeneity. Using the EB data we had four

\footnotetext{
${ }^{1}$ A more detailed analysis on consumers' price dissatisfaction in the electricity market can be found in Fiorio and Florio (2010).

${ }^{2}$ The question for the electricity service is "In general, would you say that the price you pay for the electricity supply service is fair or unfair?”, and similarly for gas and fixed telecom services.
} 
separate cross-sections comprising over 50,000 individual opinions about electricity and telecommunication prices and around 30,000 about natural gas prices. ${ }^{3}$

As for the regulatory reform variables, including measures of entry regulation, public ownership, market structure, vertical integration, in varying levels of detail, we used data provided by the ECTR data set. These data have a yearly frequency, are available since 1975 and up to 2007 and present detailed information allowing one to capture the industry-specific trends of reforms in both sectors considered here. As mentioned in Section 2, each ETCR score, going from 0 to 6, is computed as a weighted average of public ownership, vertical integration, market structure and entry regulation scores, by assigning a cardinal measure to variables that are only ordinal.

We use the overall ETCR score as an indicator of the overall reform but then we introduced our own coding of subindicators. In particular, we defined dummy variables where only ordinal variables are available in the first place. For instance, for each industry, we defined a dummy variable for public ownership equal to 1 if the industry is "public" and zero otherwise. A dummy variable for entry regulation equal to 1 if there is "no third party access, full entry regulation” and zero otherwise. A dummy variable for vertical integration equal to 1 if the industry is "vertically integrated" and zero otherwise. This approach avoids any possible measurement bias with cardinalisation as in the original ETCR scores. No market structure measure is available for electricity, while the market structure dummy for the gas industry is equal to 1 if the market share in all segments of the industry is larger than $90 \%$ (for more details on the question addressed in the ECTR database, the original and our coding, refer to Table 2 and Table 3).

[Table 2 and Table 3 about here]

Price perceptions by consumers may capture individual information misrepresented by average statistical data on prices, but subjective bias and information noise in perceptions can arise. Moreover, policy adoption or reversal can be influenced by perceptions. These data can also be criticised on several grounds as subjective evidence is notoriously fickle. For instance, there might be a "hedonic treadmill"

\footnotetext{
${ }^{3}$ Respondents about gas prices were fewer as in some countries (e.g. Greece, Portugal, Sweden) there is often very limited natural gas service provision.
} 
effect whereby satisfaction changes with outcomes so that, for example, if a country has enjoyed a big price cut in one period, consumers expect this again and are dissatisfied if this does not happen again in the next period. ${ }^{4}$

We use subjective dissatisfaction data to be analysed with dichotomous dependent variable models. The model for consumer price dissatisfaction rests on the definition of a variable disentangling satisfied from relatively dissatisfied consumers regarding the price paid for a particular network service. This variable is recorder equal to 0 if individual $j$ in country $i$ at time $t$ states that the price he pays for fixed telephone services is fair, and is recorded equal to 1 otherwise. We then estimate a standard probit model for individual dissatisfaction, where we control for year and country fixed effects, a vector of individual characteristics (i.e. sex, occupation, etc.) accounting for individual observed heterogeneity, a vector of macroeconomic control variables including population density, GDP levels, consumer price index and the total price (including all taxes) of a unit of each industry’s provided service. Finally, we control for a set of regulatory variables.

We estimate this probit models with maximum likelihood for each industry and interpret any significant coefficient in the vector of regulatory variables as a sign of the fact that regulatory reforms have some effect on consumer satisfaction regarding prices. A priori, we have no expectation as for the statistical significance nor for the sign of the coefficients of the regulatory variables. ${ }^{5}$

Table 4 shows results for dissatisfaction with electricity prices, focussing on regulatory variables only. ${ }^{6}$ The first column shows no significant correlation with the overall reform indicator and dissatisfaction with electricity prices paid by the European consumer. As the ECTR score might hide important information, we estimated the probit model replacing the ECTR score with regulatory dummies and found that the likelihood of dissatisfaction is roughly $10 \%$ lower in countries where there is public ownership of the electricity industry, even after controlling for country fixed effects. The other regulatory variables considered show that less liberalisation, as measured by less vertical integration and less constraints to enter the market, increase dissatisfaction among consumers, although entry regulation dummies are

\footnotetext{
${ }^{4}$ For a seminar paper on this issue, see Kahneman et al. (1986).

${ }^{5}$ See our discussion below about possible directions of price changes following reforms.
} 
statistically significant only when vertical integration variables are omitted, due to multicollinearity.

\section{[Table 4 about here]}

As for the analysis of gas supply dissatisfaction, Table 5 shows similar results as for public ownership. While the other liberalisation variables are not statistically significant, the overall reform indicator is estimated to have a significant and negative sign, meaning that the more advance the reform process is (i.e. the lower the GR index) the higher is dissatisfaction.

\section{[Table 5 about here]}

With all the caution one might reasonably have about using self-assessed satisfaction with prices paid by consumers, these results suggest that there is a consistent difference in dissatisfaction among EU citizens depending on how far their country is gone in privatisation and other reforms. This motivates the rest of the paper. Are these perceptions justified by actual price changes?

\section{EARLIER LITERATURE}

Consumers' dissatisfaction about the prices paid for energy after privatisation can be biased and we need to turn to a more traditional question. Can we predict how prices may respond to privatisation and regulatory reforms of utilities? The case for privatisation is reviewed, inter alia, by Bös (1991),Vickers and Yarrow (1993), Parker (1998), Newbery (2000), Florio (2004), Megginson (2005), Roland (2008). On the issue of the welfare impact of privatisation a seminal paper by Sappington and Stiglitz (1987) established the conditions for indifference between public and private ownership. They show that under different information structures a benevolent policy-maker who can write complete contracts achieves the same welfare outcomes of private owners. This result prompted two research lines: privatisation under incomplete contracts, see Schmidt (1996), where the government is unable to get all the information needed to achieve the Sappington-Stiglitz result; or privatisation where the policy makers have a private agenda, see Shapiro and Willig (1990). On the incomplete contract side the divestiture of public ownership is seen as a mechanism that prevents governments to achieve full information and to

\footnotetext{
${ }^{6}$ For the results showing macroeconomic and individual controls, see the Appendix.
} 
wipe away agent's rents. The regulator gives information rents to private agents in exchange of efficiency-enhancing investment. Hence social welfare increases. The model rests, inter alia, on the assumption that the private agent only has the capital, or knowledge, or the incentives to sink new investment. On a different vein Laffont and Tirole (1993) stress the trade off that the managers face when they need to respond to private owners and to regulators. This is a multi-principal context in which privatisation can be socially beneficial if the objectives of managers and of shareholders are more aligned than the objectives of the manager and the regulator. In this context, similar outcomes can be obtained by different layers of government or different offices in charge of ownership, management and regulation of the utility. Thus, the hypothesis that privatisation is rooted in the limited commitment credibility of government does not provide a clear-cut answer to our question. If privatisation enhances efficiency through information rents given to the agent, unit cost may decrease more than the mark-up on costs, but the same result may be achieved by a combination of public ownership, managerial discretion, and independent regulation. When quality is also considered, as by Hart, Shleifer and Vishny (1997), several outcomes are possible, and in general privatisation is less desirable where competition is limited. The distinction between privatisation and liberalisation is a core one. In Vickers and Yarrow (1993, p. 44) words: “Where product markets are competitive, it is more likely that the benefits of private monitoring (e.g. improved internal efficiency) will exceed any accompanying detriments (e.g. worsened allocative efficiency)[...]. In the absence of vigorous product market competition, however, the balance of advantage is less clear cut, and much will depend upon the effectiveness of regulatory policy".

Turning to the public choice strand of privatisation theory, it rests on the realistic hypothesis that policy makers have private agenda and they distort the management of utilities to favour rent extraction. Earlier models, such as Boycko, Shleifer and Vishny (1996) tend to say that the divestiture of public ownership is welfare enhancing because transfers between the Treasury and the utility are more transparent, and this limits rent extractions by politicians. It is, however unclear, in this context, why politicians would sell public enterprises, as they did on a huge scale in the last twenty years. Florio (2004) observes the inconsistency of assuming 
benevolent policy makers under privatisation and non-benevolent ones under nationalisation. Laffont (2005) presents a model where privatisation occurs with a corrupted government, and shows under some assumptions that the welfare outcome is non linear in corruption, and that in some case privatisation occurs for the "wrong" reasons, i.e. as an alternative way to extract rents by the politician. Thus, also the second strand of privatisation theory, while in general more suspicious about the role of government ownership, cannot provide a clear message about the direction of change of prices after privatisation, because much will depend again upon a public office, the regulator. If the regulator is non-benevolent, collusion between the privatised incumbent and the regulated utility can reverse the expected benefits of the divestiture of public ownership.

Turning now to regulatory issues, important insights are given (selectively citing from a very wide literature) by Newbery (2000), Laffont (2005), Rey and Vergè (2008), Rey and Tirole (2007). According to Newbery (2000) the restructuring of network industries should take advantage from differences in economies of scale of different segments, with the physical network usually showing sub-additive costs, while several upstream and downstream activities operate under a regime of constant or decreasing returns to scale. This leads to a paradigm of reform where vertical disintegration of the network is a crucial step, and access regulation is the institutional mechanism that would allow for competition in other activities. One way to evaluate this reform paradigm is to see unbundling as a structural remedy to market foreclosure (Rey and Tirole, 2007). Rey and Vergé (2008) show that the welfare effects of vertical restraints are crucially different according to a number of features. They conclude that while the impact on aggregate profits of a 'vertical structure' (and vertical integration can be seen as an extreme case of such arrangement) is positive, the impact on consumer surplus is ambiguous. Provisions that wipe away double marginalisation, occurring where each of the different players has some market power, may be welfare enhancing. Thus, their policy conclusion is that "the optimal policy towards vertical restraints cannot be one such that some particular provisions are deemed illegal per se while some others are always acceptable". In fact, the balance of the welfare impact of ownership unbundling depends upon the extent of the double marginalisation effect versus the entry effect. 
When we combine this relativistic policy conclusion, with the also relativistic conclusion of the discussion on privatisation in a realistic setting with incomplete contracts and various degrees of government benevolence, it seems difficult to predict price direction changes based on a robust general reform paradigm of network industries. Ceriani and Florio (2010) analyse theoretically the effect of different stages of reforms on consumers' welfare, and show that the evaluation of the reform outcomes of network industries is essentially an empirical matter: it depends upon a set of parameters that easily lead to non-linear outcomes along the reform 'line'.

Turning then to earlier empirical literature, as for electricity, Hattori and Tsutsui (2004) look at 19 OECD countries (1987-1999) and consider both industrial prices and the ratio between industrial/household prices. They find some support for privatisation and liberalisation as determining price decrease. Steiner (2000), however, in a study of 19 OECD countries (1986-1996), finds that privatisation (and time to it) increases prices, while unbundling and liberalisation have the opposite effect. Zhang et al. (2002) study electricity residential prices in 51 developing countries (1985-2000) and find no effects of the reforms. Martin and Vansteenkiste (2001) do not find an impact of liberalisation on prices, and find that public ownership increases prices in the EU15, in the very short period they consider (19952000). More recently, Gassner et al. (2009), in a detailed empirical study for the World Bank on 1,200 utilities in 71 developing and transition countries over ten years, including publicly owned and private sector participated ones, and with a different regulatory index, use differences-in-differences econometric techniques. They find that privatisation does not have an impact on prices and investment.

Finally, there is very little, as far as we know, about rigorous testing regulatory reform in the gas industry. Copenhagen Economics (2005) is supportive of the reforms while Growitsch and Stronzik (2008) do not find a significant impact of ownership change, while some negative effect of market liberalisation. Brau et al. (2010) find that there is limited evidence of beneficial effects for European consumers from the standard package of gas industry reforms. 


\section{OUR APPROACH TO THE EMPIRICAL ANALYSIS}

Our empirical strategy is simple and straightforward. We want to answer the following research question: are privatisation and liberalisation associated with lower consumer prices? In other words, can we say that consumer perceptions are somehow not grounded on real evidence and their perception of energy price fairness is biased?

We want to test whether consumers actually pay less when we observe a reform, looking at average consumer prices, controlling for relevant explanatory variables. This research question tests hard 'objective' evidence on prices, but it contains a potential aggregation error, as only prices for average consumers are available in cross-country data sets. A realistic example is when there is a change in the degree or the orientation of price discrimination. The analysis of softer 'subjective' evidence of individual users' satisfaction with prices is perhaps a proxy of consumer surplus, but it may contain a different type of error, if individuals are biased in their perceptions. Looking, however, at both individual perceptions and real average prices seems interesting. If the empirical findings are mutually consistent, despite the different nature of the potential errors, the evidence on the impact of the reforms would be reinforced. Moreover, the second research question is also interesting in a political economy perspective.

In our empirical analysis of average prices, a reduced form model for prices is specified and estimated, including, as explanatory variables, year fixed effects to capture the common trend across the EU, aggregate or detailed measures of the level of privatisation and liberalisation of the sector, controlling also for year fixed effects and other macroeconomic variables.

The structural and evolutionary differences across the two energy industries justify why, while retaining a common empirical approach, our models have industryspecific ingredients in terms of explanatory variables and controls.

Following Blundell and Bond (1998, 2000) and Bond et al. (2003) we first study the autoregressive (AR) properties of the average consumer price for each industry. As we find evidence of prices following AR(1) processes (cf. Table A1 in the appendix), the econometric analysis of consumer prices is performed by using dynamic panel data models, i.e. including among regressors also the lagged dependent variable for explaining the strong persistence of prices measures. 
For each energy sector, let $P_{i t}$ be a measure of current net-of-tax (log) prices for country $i$ at time $t, R_{i t}$ the set of regulatory variables, which might include a score of the level of regulatory regime in each industry or measures of entry regulation, public ownership, market structure, vertical integration, ${ }^{7}$ and $X_{i t}$ a set of control variables. $^{8}$ The model for price levels is:

$$
\begin{aligned}
& P_{i t}=\alpha P_{i, t-1}+R^{\prime}{ }_{i t} \beta+X^{\prime}{ }_{i t} \gamma+\delta_{t}+\varepsilon_{i t} \\
& \varepsilon_{i t}=\left(\eta_{i}+v_{i t}\right) \text { with } i=1, \ldots, I ; t=1, \ldots, T .
\end{aligned}
$$

The year-specific intercept $\left(\delta_{t}\right)$ is included to account for common cyclical or trend components in prices, preventing a likely form of cross-country correlation. A key assumption of this kind of models is that of independence of the idiosyncratic disturbances $\left(v_{i t}\right)$ across countries. We treat the individual effects $\left(\eta_{i}\right)$ as stochastic, which implies that they are correlated with the lagged dependent variable $\left(P_{i, t-1}\right)$, unless the distribution of the $\eta_{i}$ is degenerate. We also allow the control variables ( $X_{i t}$ ) and the regulatory variables $\left(R_{i t}\right)$ to be correlated with the individual effect $\eta_{i}$. Maintaining that the $v_{i t}$ component of the error term is serially uncorrelated, we then assume that $X_{i t}$ is strictly exogenous (i.e. uncorrelated with all past, present and future realisation of $v_{i t}$ ). As for the set of reform variables $R_{i t}$, we assume that they might be correlated with the unobserved error term but that, due to the political and decisional process involved, they react with some lag to changes in $v_{i t}$. In other words, we assume that $R_{i t}$ is predeterminate (i.e. $R_{i t}$ and $v_{i t}$ are uncorrelated, but $R_{i t}$ may be correlated with $v_{i, t-1}$ and earlier shocks).

The assumption of stochastic individual effects implies that they are correlated by definition with $P_{i t}$, and possibly also with $X_{i t}$ and $R_{i t}$. Hence, we estimate our model using Generalised Method of Moments (GMM) which, by using extra moment

\footnotetext{
${ }^{7}$ We also considered introducing as regulatory variable the years spanned since the establishment of the sectoral independent authority (cf. Table 5) but in no regression this variable was statistically significant, hence it was omitted from estimations.

${ }^{8}$ Although we tested for several demand and sector specific variables, including input costs and efficiency indicators, we retained only those which proved statistically significant in at least one of the specification considered.
} 
conditions, produce consistent and efficient estimates, coping with endogeneity of the lagged dependent variable.

In fact, as no external instrument is usually available outside the immediate data set, an alternative to OLS and Within estimates is to either transform the data to eliminate the individual effects or find some instruments which are orthogonal with the error term but not with endogenous regressors. Arellano and Bond (1991) suggested $^{9}$ transforming the data in first-difference eliminating the fixed effect, although the lagged dependent variable remains potentially endogenous, as the $y_{i, t-1}$ term in $\Delta y_{i, t-1}=y_{i, t-1}-y_{i, t-2}$ is correlated with $v_{i, t-1}$ which is in $\Delta v_{i t}=v_{i t}-v_{i, t-1}$ and predetermined variables such as $\Delta R_{i t}$ become potentially endogenous because they may also be related to $v_{i, t-1}$. However, longer lags of the endogenous regressors $\left(\Delta P_{i, t-s}, \Delta R_{i, t-r}\right.$ with $\left.s=2,3, \ldots, t+2 ; r=1,2, \ldots, t+2\right)$ are orthogonal to the error and can provide additional moment conditions working in the GMM framework. ${ }^{10}$

As GMM methods, as well as other methods based on instrumental variables, crucially rely on the existence of strong moment conditions, which will be tested. In all our GMM estimates, we use a one-step GMM estimator, similarly to most applied work in this area as simulation studies have suggested very modest efficiency gains from using the two-step version, even in presence of considerable heteroskedasticity (Arellano and Bond, 1991; Blundell and Bond, 1998; Blundell et al., 2000).

We mainly use the Arellano and Bond (1991) autocorrelation test for testing whether autocorrelation in the idiosyncratic disturbance term $v_{i t}$ would render some lags invalid as instruments, which is a key identifying restriction in dynamic panel data models estimated using GMM. The test of $r$-order serial correlation is asymptotically normally distributed under the null of zero serial correlation. ${ }^{11}$

Finally, we also tested our estimates for robustness excluding one country from the sample at a time, assessing whether the results are strongly dependent on the inclusion of one particular country.

\footnotetext{
${ }^{9}$ See also Holtz-Eakin et al. (1988).

${ }^{10}$ Of course, also the orthogonality of the exogenous variables with the transformed error term is exploited and corresponding moment conditions included in all GMM estimations.

${ }^{11}$ Arellano and Bond (1991) find that their test has greater power than the Sargan/Hansen test to detect lagged instruments being invalid due to autocorrelation.
} 


\section{THE DATA}

While presenting large variability in the timing and the extent of implementation of regulatory reforms, EU15 countries also share similar institutional characteristics and a common legislative direction. The primary source for the average (log) price variables are the International Energy Agency (IEA). The only alternative data source available for a EU15-wide analysis would be the Eurostat, which however is available for a much shorter time series as it starts at best in 1991. Instead, the timeseries of IEA data start in 1978, providing over 30 time series (some summary statistics are provided in the appendix, Table A 3). The IEA net-of-tax electricity and gas prices for households are expressed in €/unit and present a correlation with household net-of-tax electricity prices (yearly consumption of $3500 \mathrm{kWh}$ of which night 1300 ) and gas prices (yearly consumption: $83.70 \mathrm{GJ}$ ) from Eurostat data equal to 0.814 and 0.847 , respectively. ${ }^{12}$

As for the regulatory reform variables, including measures of entry regulation, public ownership, market structure, vertical integration, in varying levels of detail, we used data provided by the ETCR data set and already introduced in Subsection 3.1.

\section{RESULTS}

Table 7 and Table 8 present the result of the estimation of various specifications of model (1) for the electricity and gas prices, respectively. These tables share the same structure, although they are estimated separately. The first column provides a test of the reform as a whole estimating model (1) where the reform variable $R$ is the ETCR sector score ranging from 0 to 6 . In the following columns, we use as reform variables the set of dichotomous dummy variables, as described in Section 6. All models are estimated using GMM.

Due to the small dimension of the whole panel, and following Blundell and Bond (2000) who discuss the possibility that the error term might have a small degree of autocorrelation due to measurement errors, we estimate these models using as

\footnotetext{
${ }^{12}$ IEA monetary variables, which are expressed in US\$, were converted into euro using the Eurostat euro/US\$ exchange rate.
} 
instruments the three most recent lags of the dependent variable starting from period $t$-3. All estimated models pass the key identification test allowing for zero secondorder autocorrelation of residuals, as well as the Sargan test for over-identifying restrictions. All models are estimated using robust estimation as tests of homoskedasticity of residuals always rejects the null.

The highly significant lagged dependent variable sheds doubt over similar panel data models in earlier literature without a dynamic specification, whose estimates are very likely to be affected by omitted variable bias, as discussed in the Appendix (Table A 2).

As for the electricity industry (Table 7), it is interesting to notice that the lagged dependent variable is highly significant also after inclusion of year fixed-effects, regulatory variables and other controls. If the ETCR score, ranging from 0 (full privatisation, unbundling and liberalisation) to 6 (no privatisation, vertical integration and no free entry in the industry), is included in the regression testing whether the reform package as a whole had any effect on average prices, one could conclude that no statistically significant effect is found. If, instead of the ETCR score, a dummy variable for each of the three dimensions of the electricity industry reform is included, it emerges that only public ownership variable (ERpo_d) presents a consistently significant coefficient, reducing average price by roughly 0.3 (log) points. Vertical integration, which is strongly correlated with public ownership, is never statistically significant. Entry regulation is significant at the $10 \%$ significance level although it is mainly the freedom of choice of providers that drive this effect. Interestingly, the coefficient is negative suggesting that allowing consumers to choose provider is negatively correlated with actual price paid. This could be interpreted as a consequence of more advertising expenditure by the producing firms that is reflected on average prices or on the mistakes of actual 'switcher' as recently found in the UK (Wilson and Waddams Price, 2010). Other control variables are not significantly correlated with average log prices, with the exception of per capita GDP, suggesting that electricity is a normal good.

Hence, decomposing the ETCR score into 0-1 variables, we find that evidence on average price is consistent with evidence on consumers' perception discussed in Subsection 3.1, in particular as far as public ownership is concerned. 
Remarkably, similar conclusions are also reached with respect to public ownership in the natural gas industry. Ceteris paribus, public ownership reduces price by roughly $0.2 \log$ points. None of the other regulatory variables considered are found statistically significant as well as the other demand and supply variables tested. The only exception is the price of Brent oil which is consistently an important determinant of price dynamics. Of course, this comes with no surprise as gas prices have been indexed using oil market prices since the beginning of the 1990s (Table 8).

[Table 7 and Table 8 about here]

\subsection{DIAGNOSIS AND ROBUSTNESS CHECKS}

Since Bound et al. (1995) it is well known that weak instruments can provide inconsistent estimates. Hence, similarly to Blundell and Bond (2000), we estimate a reduced form regression of the first difference $\Delta \log \left(\right.$ price $\left._{t-1}\right)$ on $\log \left(\right.$ price $\left._{t-2}\right), \log \left(\right.$ price $\left._{t-3}\right), \ldots, \log \left(\right.$ price $\left._{t-20}\right)$. A small coefficient of determination $\left(R^{2}\right)$ in any of these regressions and a Wald test of slope coefficients jointly equal zero would signal a weak instrument set. For the electricity sector we find $R^{2}=0.288$ and for the gas sector $R^{2}=0.440$, which let us conclude that the lagged log prices in levels are acceptable instruments for the endogenous lagged first difference. Moreover, the null hypothesis of all instruments being jointly zero is rejected at any reasonable confidence level.

In Section Fehler! Verweisquelle konnte nicht gefunden werden. we used GMM as the assumption of stochastic individual effects implies that they are correlated by definition with the dependent variable, $P_{i t}$, and possibly also with other covariates. If so, Ordinary Least Square (OLS) estimator of $\{\alpha, \beta, \gamma\}$ in the level equations of model (1) is inconsistent, and this correlation remains even for $T, N \rightarrow \infty$. A Within estimator would eliminate the main source of OLS inconsistency, i.e. the country fixed effect, $\eta_{i}$, however it does not completely solve the problem. In fact, for a small $T$, the Within transformation induces a correlation between the transformed lagged dependent variable and the transformed error term, producing a biased estimator (Nickel, 1981). 
Notwithstanding their biased nature, and mainly as a robustness check, we estimated the dynamic panel model (1) also using OLS and Within. Table 9 and Table 10 show OLS and Within estimates for the electricity and gas price models, respectively. Compared to the GMM results and using OLS, public ownership is now not statistically significant as most of the variability is now captured by the lagged dependent variable, which is estimated with a pointwise value very close to one. However, when Within methods are used instead, not only the lagged dependent variable coefficient reduces in magnitude but also the coefficient of public ownership is found to be negative with p-values well below $10 \%$, confirming what has been found using GMM. This result is particularly reassuring as the Within transformation, relying on a relatively long time series ( $T_{i} \geq 20$, for all $i$ ), sweeps out most of the causes of endogeneity, hence of the source of inconsistency.

[Table 9 and Table 10 about here]

Finally, as a further robustness check, we tested our estimates excluding one country from the sample at a time, for assessing whether the results are strongly dependent on the inclusion of one particular country. Results for the electricity sector are presented in Table 11 and show that, although the magnitude of some significant coefficient slightly changed the positive correlation of per capita GDP is robust as well as the negative correlation of the dummy for public ownership with prices. The negative correlation between the no-free-entry dummy (ERen_d) and prices remains statistically significant in only 6 out of 15 samples. Robustness analysis for the gas sector are presented in Table 12 and mainly confirm results obtained with the whole sample and in particular for the role of Brent oil and public ownership in the industry on price levels. It should be noted however that the p-value of the Brent coefficient is 0.132 when Spain is dropped and the p-value of the public ownership dummy is 0.169 if the UK is dropped, although the sign is in both cases consistent with overall results.

[Table 11 and Table 12 about here]

\section{CONCLUDING REMARKS AND POLICY IMPLICATIONS}

Starting from an analysis of consumers perceptions, our paper offers a check of the impact of privatisation and of liberalisation of network industries on consumer prices 
in the EU. Moreover, while the reform is often proposed as a policy package that includes privatisation, vertical disintegration, and liberalisation, we disentangle the ownership effect after controlling for other reforms. We explicitly consider dynamics, use time series longer than in earlier literature, and data sources from international organisations, such as Eurostat, IEA, OECD, the World Bank, Eurobarometer. These sources are widely available to researchers for further empirical analysis.

We summarise our findings as follows.

a) What is the overall effect of the reform package on prices and consumer satisfaction? We find that the overall impact of the reform package on consumer prices, as summarised in the ETCR industry score, is never statistically significant for electricity prices and is negatively correlated with gas prices. This is what one would expect if the adverse allocative effect of privatisation is just counterbalanced by the beneficial effect of liberalisation (see Vickers and Yarrow (1993) and our discussion in Section 4). An alternative interpretation is that the linear weights that the OECD uses for the indicator misrepresent the reforms. The results by Azmat et al. (2007), and by the earlier papers cited in the Introduction, however, strongly suggest that the OECD scores work well for several other performance variables, including productivity and investment. Our results, compared with Azmat et al. (2007), who find declining labour shares, imply an increase of the profitability of reformed industries. This fact may well sustain investment, as in Alesina et al. (2005). The combined evidence of lack of the overall reform impact on consumer prices, and of changes of the factor shares, implies a redistribution effect, that may explain the overall mixed or adverse perceptions of consumers.

b) Does privatisation per se decrease consumer prices? Our answer to the question is negative. Our discussion in Section 4 shows that if a public enterprise is very inefficient, a privatised monopoly or oligopoly, even without price regulation, can offer lower prices than the vertically integrated public monopoly, because on balance its allocative inefficiency may be less than its cost savings. We find, however, that this is certainly not true in the 
European Union. Consistently with this result, we find strong evidence of higher consumers' satisfaction with the price paid under public ownership of the energy incumbent.

Our bottom line is that while we have been able to identify a clear ownership effect, the overall evidence on the impact of liberalisation reforms on prices and consumers' satisfaction is mixed. We are not entirely surprised by this finding, because one traditional objective of public ownership was to offer low prices to consumers (sometimes by cross-subsidies) even if these sectors were profitable.

The finding is, however, entirely new and suggests two policy implications. First, while earlier reformers hoped that price caps were to be removed with full liberalisation, we suggest that under privatisation, continued monitoring and regulation of prices should be a permanent feature, because productivity gains are not necessarily passed to consumers ${ }^{13}$ with ECHP panel data. Second, we suggest that privatisation is not a panacea, and that the European Union must remain neutral about public ownership.

The belief that public ownership is necessarily associated with inefficiency, corruption, capture from vested interests (see e.g. Boycko, Shleifer and Vishny, 2003) must be assessed against the reality that private ownership under oligopoly in essential services may also be socially inefficient. Private interests have an incentive to buy regulators and law-makers in order to be allowed to enjoy market dominance or, under oligopoly, they may tend to collude. The balance of the public-private inefficiencies varies country by country, and industry by industry, or even looking at specific segments of the industry. Public ownership is not necessarily the enemy of liberalisation. Examples are the national electricity transmission system operators (TSO) in the Nordic power system, perhaps one of the most advanced in the world in terms of regional integration and market opening. Interestingly, the ownership structure of the TSOs across the four participating countries ranges from Svenka Krafnat (Sweden), a state agency, to the Danish and Norwegian TSOs (Energinet.dk and Statnett), that are corporations with the state as sole owner, to the Finnish TSO jointly owner by a private generator, institutional investors, and the Finnish state. In this context, public ownership of the networks has probably been an advantage for 
the promotion of cross-border market integration. We conclude that when there is a tradition of reasonably effective management in the public sector, for example in the Scandinavian countries, or in France, public ownership of part of the network industry, particularly the network itself, can still play a role in protecting consumers from oligopolistic exploitation. This role must be, however, assessed case by case, looking at the specific institutional environment. Thus, in our view article 295 of the EC Treaty $^{14}$ is a wise provision, in that it delegates to member states to decide whether in their national conditions public versus private provision is still an option to achieve certain objectives in the public interest.

We suggest that if privatisation is considered on efficiency grounds, its implications for consumer prices and overall satisfaction must be addressed (including compensation mechanisms for the poor, who may suffer from tariff re-balancing and other adjustments of tariff structures following the divestiture of public provision).

We suggest that in some countries and for some industries having public provision or a publicly owned network or a range of different arrangements (part-privatisation, mixed oligopoly, mutual ownership, etc.) should be allowed without any interference by the EU, as for article 295 of the Treaty, provided that (a) borders are open for capital investment and for trade, with the only limitation of national security; and that (b) any user is given the concrete right and opportunity to pick up the best possible deal in the European economic space.

The network industries are still far from the competitive paradigm. One of the leading British experts in the energy sector, after having reviewed two decades of reform in the UK, perhaps the inspiring model for the current EC approach, concluded : ' in 1980s ad 1990s the pendulum swung too far the other way (from public monopoly). The market enthusiasts failed to the recognize how far the electricity market deviated from the normal commodity model. To recap, supply must instantaneously match demand as there is limited scope for storage: the assets are sunk or long lived, the networks are natural monopolies. There are very great environmental externalities; and critically, electricity and gas are complementary to

\footnotetext{
${ }^{13}$ Particularly to most vulnerable ones, as found by Florio and Poggi (2010).

${ }^{14}$ In fact, Article 295 of the EC Treaty states: “ This Treaty shall in no way prejudice the rules in Member States governing the system of property ownership”. This article was included in the 1957 Treaty to allow nationalisation of certain industries, and has not been changed over half century.
} 
the rest of the economy, in that failure to supply has (extremely) large costs to all economic activity. It is hard to think of any other activity in modern developed economies with quite such coincidence of major market failures. If the issue of fuel poverty and the distributional implications of electricity and gas pricing and supply are also included, it is extraordinary that anyone could have regarded these as anything other than political industries”. (Helm, 2003, p.407).

Our findings offer some support to this view and tend to reject a more simplistic reform paradigm based on the same features, particularly privatisation everywhere.

\section{Acknowledgments}

We are very grateful to participants to the OECD/CESifo Workshop (Munich), and the EPRG Spring Research Seminar (Cambridge), and to many colleagues, particularly to Massimiliano Bratti, Paolo Garella, Marzio Galeotti, Matteo Manera and Franco Peracchi for fruitful discussions on earlier versions of this paper. We also thank Elisa Borghi for competent research assistance. This paper is part of a research project "Understanding privatisation: political economy and welfare effects", supported by the European Union, VI Framework Programme, with FEEM as coordinating unit, and teams from Milan University, Pompeu Fabra, Amsterdam University, CERGE-EI (Prague), IFO (Munich), and OECD.

\section{REFERENCES}

Alesina, A, Ardagna, S., Nicoletti, G. and F. Schiantarelli (2005). Regulation and investment, Journal of the European Economic Association, June, 3(4):791-825

Arellano, M. and Bond, S. (1991). Some tests of specification for panel data: Monte Carlo evidence and an application to employment equations. Review of Economic Studies, 58:277-97.

Azmat,G., Manning, A. and Van Reenen, J. (2007). Privatization, entry regulation and the decline of labour's share of GDP: a cross-country analysis of the network industries, CEPR Discussion Paper No. 6348, June.

Blundell, R.W. and Bond, S.R. (1998). "Initial conditions and moment restrictions in dynamic panel data models”, Journal of Econometrics, Elsevier, vol. 87(1), pages 115143, August

Blundell, R.W. and Bond, S.R. (2000). "GMM estimation with persistent panel data: an application to production functions”, Econometrics Reviews, 19, 321-340.

Blundell, R.W., Bond, S.R. and Windmeijer, F. (2000), Estimation in dynamic panel data models: improving on the performance of standard GMM estimator in B. Baltagi (ed.) Advances in Econometrics, Volume 15: Nonstationary panels, panel cointegration and dynamic panels, JAI Elsevier Science.

Bond, S., Elston, J., Mairesse, J., Mulkay, B. (2003). Financial factors and investment in Belgium, France, Germany and the UK: a comparison using company panel data. Review of Economics and Statistics 85, 153-177.

Bös, D. (1991), Privatization, A Theoretical Treatment, Clarendon Press, Oxford 
Bound, J., Jaeger, D.A. and Baker, R.M. (1995), Problems with instrumental variables estimation when the correlation between the instruments and the endogenous explanatory variable is weak, Journal of the American Statistical Association, vol. 90, No. 430, 443-450.

Boycko M., Shleifer A., Vishny R, (1996), A theory of Privatization, Economic Journal, 106, 309-319

Brau, R., Doronzo, R., Fiorio, C.V. and Florio, M., (2010), "EU gas industry reforms and consumers' prices”, The Energy Journal, Vol. 31, No. 4, pp. 163-178.

Ceriani L., Florio, M. (2008). Consumer's Surplus and the Reform of Network industries: A Primer, DEAS Working Papers n. 23.

Checchi, D., Florio, M. and Carrera, J. (2009). Privatization discontent and utility reform in Latin America, Journal of Development Studies, vol.45, march n.3, pp 333351

CEC, (2007). Evaluation of the Performance of Network Industries Providing Services of General Economic Interest. 2006 Report, Commission of the European Community.

Conway, P. and Nicoletti, G. (2006). Product Market Regulation in the NonManufacturing Sectors of OECD Countries: Measurement and Highlights, OECD Economics Department Working Papers 530

Copenhagen Economics (2005): Market Opening in Network Industries, Final Report prepared for DG Internal Market, European Commission, Brussels

Eurobarometer (2002). Report No. 53, "The people of Europe and Services of general interest”. Eurobarometer Survey Series, Commission of the European Communities.

Eurobarometer (2004). Report No. 58 “Consumers' Opinions about Services of General Interest”. Eurobarometer Survey Series, Commission of the European Communities.

Eurobarometer (2006). Report No. 62.1: The Constitutional Treaty, Economic Challenges, Vocational Training, Information Technology at Work, Environmental Issues, and Services of General Interest. Eurobarometer Survey Series, Commission of the European Communities.

Eurobarometer (2008). Eurobarometer 65.3: Neighbors of the European Union, Services of General Interest, Employment and Social Policy, Energy Technologies, and Family Planning. Eurobarometer Survey Series, Commission of the European Communities.

Fiorio, C.V. and Florio, M. (2010), “"Would you say that the price you pay for electricity is fair?» Consumers' satisfaction and utility reforms in the EU15”, Energy Economics, forthcoming.

Florio, M. (2004). The Great Divestiture. Evaluating the welfare impact of British privatizations 1979-1997. The MIT Press.

Florio, M and Poggi A. (2010), Energy deprivation dynamics and regulatory reforms in Europe: Evidence from household panel data, Energy Policy, vol. 38(1), pages 253264

Gassner K, Popov A., Pushak N. (2009). Does private sector participation improve performance in electricity and water distribution?, The World Bank

Growitsch, C. and M. Stronzik (2008), "Ownership Unbundling of Gas Transmission Networks - Theoretical Background and Empirical Evidence", Paper submitted to the first annual conference of the Journal Competition and Regulation in Network Industries. Downloadable at: http://crni.epfl.ch/papers/growitsch.pdf

Hart O, Shleifer A., Vishny R (1997), The proper scope of government with an application to prisons, Quartely Journal of Economics 
Hattori, T. and Tsutsui, M. (2004). Economic impact of regulatory reforms in the electricity supply industry: a panel data analysis for OECD countries, Energy Policy Vol. 32 (6), 823-832.

Helm, D (2007), The New Energy Paradigm, Oxford University Press.

Laffont, J.J. (2005). Regulation and Development, Cambridge University Press

Laffont J.J and Tirole J.(1993), A Theory of Incentives in Procurement and regulation, MIT Press, Cambridge (Mass)

Martin R. and Vansteenkiste I. (2001). EU telecommunications and electricity marketsHeading towards price convergence?, Intereconomics: Review of European Economic Policy Vol. 36(3), 131-140

Megginson W.L. (2005), The Financial Economics of Privatization, Oxford University Press

Millward R. (2005). Private and Public Enterprise in Europe:Energy, Telecommunications and Transport c.1830-1990, Cambridge University Press

Newbery D. (2000), Privatization, Restructuring and Regulation of Network Industries, MIT Press, Cambridge (Mass.)

Newbery, D. and Pollitt, M. G. (1997) "The Restructuring and Privatization of Britain's CEGB-Was It Worth It?”, Journal of Industrial Economics, Blackwell Publishing, vol. 45(3), pages 269-303, September.

Nicoletti, G. and Scarpetta, S. (2003). Regulation, productivity and growth: OECD evidence, Economic Policy, vol. 18(36), pp 9-72, 04.

Nickel, S.J. (1981), Biases in dynamic models with fixed-effects, Econometrica, 49, 1417-1426.

Parker D. (1998), Privatization in the European Union. Theory and Policy Perspectives, Routledge, London

Pollitt M., (2007). The arguments for and against ownership unbundling of energy transmission networks, Cambridge Working Papers in Economics, n 0737.

Rey P and Vergé T. (2008), Economics of Vertical restraints, in Buccirossi (ed), Handbook of Anti-Trust Economics, MIT Press, Cambridge (Mass), pp 353-390

Rey P and Tirole J, (2007) A primer on foreclosure, in Armstrong M. and Porter Robs (eds), Handbook of Industrial Organization, Vol. III, North Holland, pp 2145-2220

Roland G. (2008), Privatization: Success and failures, Columbia University Press

Sappington D. and Stiglitz J., (1987), Privatization, Information, and Incentives, Journal of Policy Analysis and Management, 6, 567-582

Schmidt K, (1996), The costs and benefits of privatization, An incomplete contracts approach, Journal of law, Economics, and Organization, 12. 1-24

Shapiro C and Willig R. (1990), Economic rationales for the scope of privatization, in E.N. Suleiman E.N. and Waterbury J (eds), The political economy of public sector reform and privatization, Westview Press, Boulder (Colorado), 55-87

Steiner F. (2000). Regulation, Industry Structure and Performance in the Electricity Supply Industry, OECD, Economics Department Working Papers No. 238.

Ugaz, C. and Waddams Price, C. (2003). Utility Privatization and Regulation: a Fair Deal for Consumers? Edward Elgar. Cheltenham.

Vickers J, Yarrow G. (1993), Privatization. An Economic Analysis, MIT Press, Cambridge (Mass)

Wilson, C.M. and C. Waddams Price (2010). "Do Consumers Switch to the Best Supplier?”. Oxford Economic Papers, forthcoming. 
Zhang, Y., Kirkpatrick, C. and Parker, D. (2002). Electricity Sector Reform in Developing Countries: An Econometric Assessment of the Effects of Privatisation, Competition and Regulation, University of Manchester, Institute for Development Policy and Management (IDPM) Working papers No. 30593. 
Figure 1: Average price, overall and public ownership ETCR scores for the energy industries.
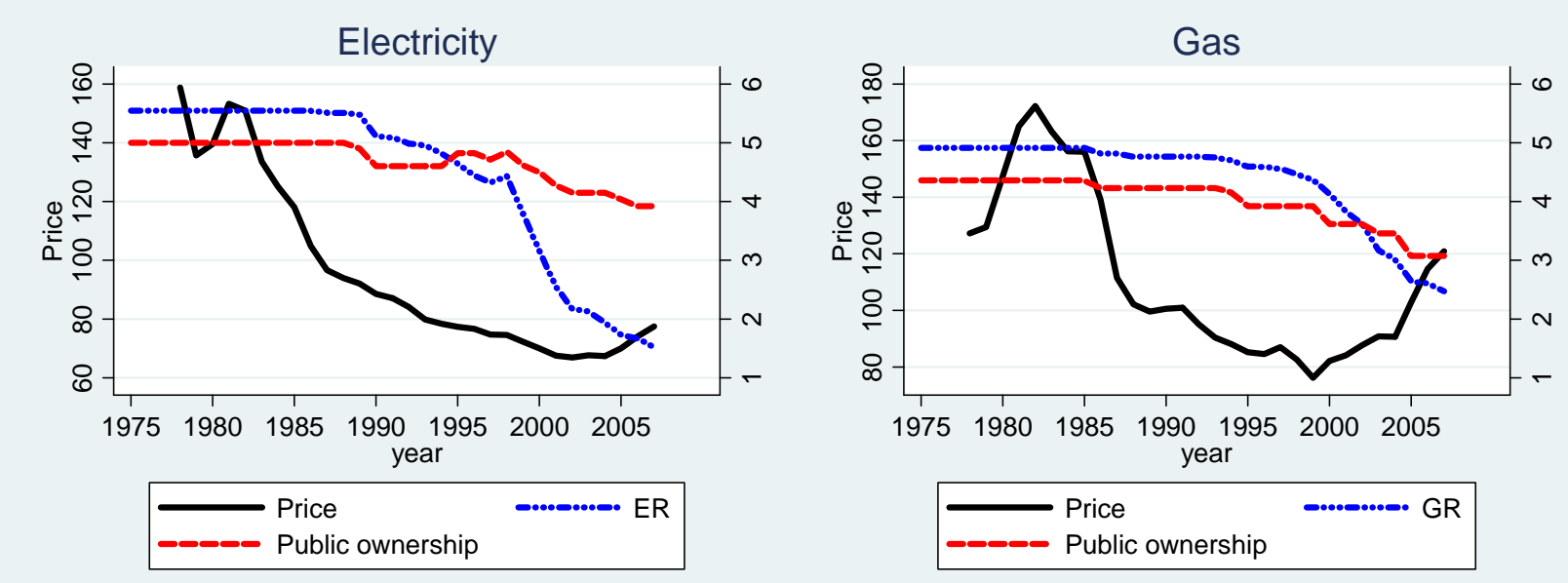

Note: Price (source: IEA) deflated using the national CPI (source: WDI), at 1978 base price. Price scale on the on the left axis, ECTR indices scale on the right axis. ER and Public ownership are ETCR 0-6 scores for the whole industry and its public ownership dimension, respecively

Table 1: Price trends and report scores for the EU15, France and the UK.

\begin{tabular}{|c|c|c|c|c|c|c|c|c|c|}
\hline \multirow{4}{*}{ France } & & 1978 & 1990 & 1995 & 2000 & 2003 & 2004 & 2005 & 2006 \\
\hline & & \multicolumn{8}{|c|}{ ELECTRICITY } \\
\hline & Price & 0.14 & 0.11 & 0.11 & 0.09 & 0.08 & 0.08 & 0.08 & 0.08 \\
\hline & ETCR score & 6.00 & 6.00 & 6.00 & 4.28 & 3.61 & 2.61 & 2.61 & 2.11 \\
\hline \multirow[t]{2}{*}{ UK } & Price & 0.14 & 0.13 & 0.10 & 0.11 & 0.09 & 0.10 & 0.10 & 0.12 \\
\hline & ETCR score & 6.00 & 0.83 & 0.11 & 0.00 & 0.00 & 0.00 & 0.00 & 0.00 \\
\hline \multirow{2}{*}{ EU15-average } & Price & 0.22 & 0.12 & 0.11 & 0.10 & 0.09 & 0.09 & 0.10 & 0.10 \\
\hline & ETCR score & 5.54 & 5.11 & 4.64 & 3.16 & 2.13 & 1.94 & 1.73 & 1.67 \\
\hline \multirow{2}{*}{ EU15-st. dev. } & Price & 0.24 & 0.04 & 0.03 & 0.02 & 0.02 & 0.02 & 0.02 & 0.02 \\
\hline & ETCR score & 0.61 & 1.36 & 1.57 & 1.54 & 1.05 & 0.96 & 0.82 & 0.81 \\
\hline
\end{tabular}

\begin{tabular}{l|llllllllll}
\multirow{2}{*}{ France } & & price & 12.63 & 8.89 & 8.11 & 7.65 & 8.87 & 8.26 & 8.78 & 10.22 \\
& ETCR score & 6.00 & 6.00 & 6.00 & 6.00 & 3.67 & 3.49 & 2.24 & 2.24 \\
\hline \multirow{2}{*}{ UK } & price & 8.75 & 8.33 & 6.35 & 7.21 & 6.64 & 7.06 & 7.81 & 10.02 \\
& ETCR score & 5.75 & 3.50 & 3.03 & 1.90 & 1.65 & 1.10 & 0.73 & 0.73 \\
\hline \multirow{2}{*}{ EU15- average } & price & 11.26 & 8.91 & 7.54 & 7.27 & 8.04 & 8.02 & 9.11 & 10.14 \\
& ETCR score & 4.92 & 4.77 & 4.59 & 4.13 & 3.17 & 3.02 & 2.64 & 2.61 \\
\hline \multirow{2}{*}{ EU15-st. dev. } & price & 6.62 & 3.47 & 2.29 & 1.96 & 2.64 & 2.68 & 2.64 & 2.85 \\
& ETCR score & 0.83 & 0.87 & 0.87 & 1.23 & 1.12 & 1.24 & 1.17 & 1.12 \\
\hline
\end{tabular}

Source: Authors' calculations using IEA, WDI and ETCR data.

Note: Prices converted into current euro using Eurostat €/USD exchange rate. 
Table 2: The ETCR indicator for the electricity industry with our coding.

ELECTRICITY

PUBLIC OWNERSHIP:

What is the ownership structure of the largest companies in the generation, transmission, distribution, and supply segments of the electricity industry? (ERpo1)

ENTRY REGULATION:

How are the terms and conditions of third party access (TPA) to the electricity transmission grid determined? (ERen1)*

Is there a liberalised wholesale market for electricity (a wholesale pool)? (ERen2)*

What is the minimum consumption threshold that consumers must exceed in order to be able to choose their electricity supplier ? (ERen3)* VERTICAL INTEGRATION:

What is the degree of vertical separation between the transmission and generation segments of the electricity industry? (ERvi1)

What is the overall degree of vertical integration in the electricity industry? (ERvi2)

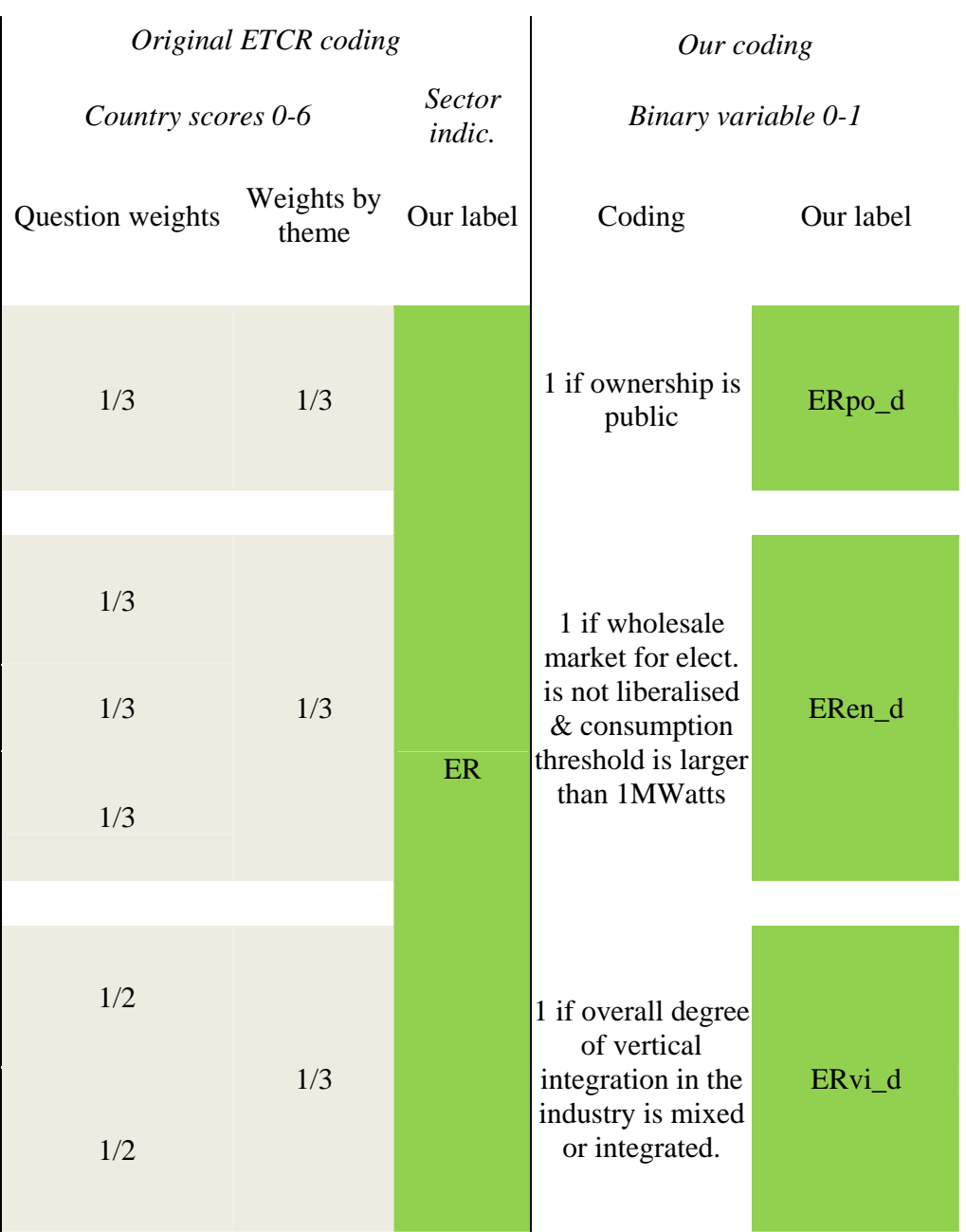

Source: ETCR coding taken from Conway and Nicoletti (2006).

Notes:

* ERen1_d is coded 1 if there is no third party access, and 0 otherwise. ERen2_d is coded 1 if there is no liberalised whole sale market for eletricity, and 0 otherwise. ERen3_d is coded 1 if there exist a minimum threshold that consumers must exceed in order to be able to choose their electricity supplier and 0 otherwise. 


\section{Table 3: The ETCR indicator for the natural gas industry with our coding.}

GAS

$\begin{array}{cc}\text { Original ETCR coding } \\ \text { Country scores } 0-6 \quad \begin{array}{c}\text { Sector } \\ \text { indic. }\end{array} \\ \text { Question weights } \begin{array}{cc}\text { Weights } \\ \text { by theme }\end{array} & \begin{array}{c}\text { Our } \\ \text { label }\end{array}\end{array}$

\section{PUBLIC OWNERSHIP:}

What percentage of shares in the largest firm in the gas production/import sector are owned by government?

What percentage of shares in the largest firm in the gas transmission sector are owned by government?

What percentage of shares in the largest firm in the gas distribution sector are owned by government?

ENTRY REGULATION:

How are the terms and conditions of third party access (TPA) to the gas transmission grid determined?

What percentage of the retail market is open to consumer choice?

$1 / 3$

Do national, state or provincial laws or other regulations restrict the number of competitors allowed to operate a business in at least some markets in the sector: gas production/import

MARKET STRUCTURE:

What is the market share of the largest company in the gas production/import industry?

What is the market share of the largest company in the gas transmission industry?

What is the market share of the largest company in the gas supply industry?

VERTICAL INTEGRATION:

What is the degree of vertical separation between gas production/import and the other segments of the industry?

What is the degree of vertical separation between gas supply and the other segments of the industry?

Is gas distribution vertically separate from gas supply?

Source: ETCR coding taken from Conway and Nicoletti (2006).
$1 / 3$

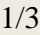

$1 / 3$

$1 / 4$

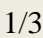

$1 / 3$

$1 / 3$

$1 / 4$

$1 / 3$

$1 / 3$

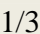

$1 / 4$

$1 / 3$

Our coding

Binary variable 0-1

Coding (zero otherwise)

Our label

1 if $100 \%$ of ownership of shares in all segments of the industry is public

GRpo_d

1 if no third party access, no consumers' choice in the retail market, and restrictions operate in all markets.

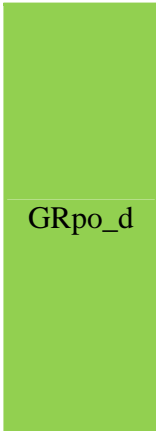

GRen_d

1 if market share in all segments of the GRms_d industry is larger than $90 \%$

if the industry is integrated in all segments 
Table 4: Consumers' dissatisfaction with electricity prices.

Dependent variable: individual dissatisfaction with prices paid for electricity supply

Overall reform

ER $\quad-0.009$

$(0.701)$

\begin{tabular}{|c|c|c|c|c|c|c|}
\hline \multicolumn{7}{|l|}{ Public ownership } \\
\hline ERpo_d & & $\begin{array}{l}-0.105^{* * *} \\
(0.003)\end{array}$ & $\begin{array}{l}-0.088 * * \\
(0.037)\end{array}$ & $\begin{array}{l}-0.102^{* * *} \\
(0.003)\end{array}$ & $\begin{array}{l}-0.101^{* * *} \\
(0.006)\end{array}$ & $\begin{array}{l}-0.115^{* * *} \\
(0.000)\end{array}$ \\
\hline \multicolumn{7}{|l|}{ Vertical integration } \\
\hline ERvi_d & & $\begin{array}{l}0.039 * * \\
(0.038)\end{array}$ & $\begin{array}{l}0.039 * \\
(0.051)\end{array}$ & $\begin{array}{l}0.037 * \\
(0.059)\end{array}$ & & \\
\hline \multicolumn{7}{|l|}{ Entry regulation } \\
\hline ERen_d & & $\begin{array}{l}0.024 \\
(0.538)\end{array}$ & & & & \\
\hline ERen1_d & & & $\begin{array}{l}-0.066 \\
(0.237)\end{array}$ & & $\begin{array}{l}-0.054 \\
(0.345)\end{array}$ & \\
\hline ERen2_d & & & $\begin{array}{l}0.000 \\
(0.990)\end{array}$ & & $\begin{array}{l}0.015 \\
(0.563)\end{array}$ & \\
\hline ERen3_d & & & $\begin{array}{l}0.030 \\
(0.196) \\
\end{array}$ & $\begin{array}{l}0.031 \\
(0.101)\end{array}$ & $\begin{array}{l}0.050^{*} \\
(0.053) \\
\end{array}$ & $\begin{array}{l}0.047 * * \\
(0.042)\end{array}$ \\
\hline Electricity price for an average consumer & yes & Yes & yes & yes & yes & yes \\
\hline Per capita GDP & yes & Yes & yes & yes & yes & yes \\
\hline Year fixed-effects & yes & Yes & yes & yes & yes & yes \\
\hline Individual characteristics & yes & Yes & yes & yes & yes & yes \\
\hline Country fixed-effects & yes & Yes & yes & yes & yes & yes \\
\hline
\end{tabular}

Marginal effects are reported. Robust p-values in parentheses. Std. Err. adjusted for 15 country clusters.

*** $\mathrm{p}<0.01, * * \mathrm{p}<0.05, * \mathrm{p}<0.1$

Legend:

ER is the ETCR 0-6 score; ERpo_d is 1 if ownership is public, 0 o.w.; ERvi_d is 1 if overall degree of vertical integration in the industry is mixed or integrated, 0 o.w.; ERen_d is 1 if wholesale market for elect. is not liberalised \& consumption threshold is larger than 1MWatts, 0 o.w.; ERen1_d is 1 if there is no third party access to the electricity transmission grid, 0 o.w.; ERen2_d is 1 if there is no liberalised wholesale market for electricity, 0 o.w.; ERen3 is the minimum consumption threshold that consumers must exceed in order to be able to choose their electricity supplier in a 0-6 scale. 


\section{Table 5: Consumers' dissatisfaction with gas supply prices.}

Dependent variable: individual dissatisfaction with prices paid for gas supply

\section{Overall reform}

GR

Public ownership

GRpo d

$-0.134 * * *$

$-0.131^{* * *}$

$-0.132 * * *$

$(0.000)$

(0.000)

$(0.000)$

Vertical integration

GRvi_d

$\begin{array}{lll}-0.050 & -0.004 & -0.009\end{array}$

$(0.450) \quad(0.968)$

Entry regulation

GRen_d

(0.810)

GRen1_d

GRen3_d

GRen2

(0.513)

Gas price for an average consumer

Per capita GDP

yes

Year fixed-effects

Individual characteristics

yes yes

yes

Country fixed-effects

yes yes

yes

yes

yes yes

yes

yes

Marginal effects are reported. Robust p-values in parentheses. Std. Err. adjusted for 15 country clusters.

*** $\mathrm{p}<0.01, * * \mathrm{p}<0.05, * \mathrm{p}<0.1$

Legend:

GR is the ETCR 0-6 score; GRpo_d is 1 if 1 if 100\% of ownership of shares in all segments of the industry is public, 0 o.w.; GRvi_d is 1 if the industry is integrated in all segments, 0 o.w.; GRen_d is 1 if no third party access, no consumers' choice in the retail market, and restrictions operate in all markets., 0 o.w.; GRen1_d is 1 if there is no third party access to the gas transmission grid, 0 o.w.; GRen3_d is 1 if national, state or provincial laws or other regulations restrict the number of competitors allowed to operate a business in all markets in the gas production/import sector, 0 o.w.; GRen2 is the percentage of the retail market open to consumer choice in a 0-6 scale. 


\section{Table 6: Definitions of main variables used in the price equation models.}

Label

EAprinet

ER, ERpo_d, ERen_d, ERvi_d

EAscmbf

EAimports

EArescons

MWgdppc

GR, GRpo_d, GRen_d, GRvi_d

GAbrent

Price of Brent oil (Source: IEA; (a))

Notes: Variables starting with an "l", means that they were transformed in logarithms. (a) Original data are in US\$ and were converted to $€$ using Eurostat euro/USD average yearly exchange rate.

\section{ELECTRICITY}

Electricity net-of-tax price for households, submitted to the IEA Secretariat by Administrations (in €/unit) (Source: IEA; (a))

See Table 2

Electricity source: Total Combu. Fuels (GWh/Tj) (IEA)

Electricity import (GWh) (Source: IEA; (a))

Electricity residential consumtion (GWh) (Source: IEA; (a))

Nominal GDP (billion of euro) (Source: WDI; (a))

\section{GAS}

Natural gas net-of-tax price for households, submitted to the IEA Secretariat by Administrations (in $€ /$ unit) (SourceIEA; (a))

See Table 3 
Table 7: GMM estimation of dynamic panels for electricity prices.

\begin{tabular}{|c|c|c|c|c|c|}
\hline & (1) & (2) & (3) & (4) & (5) \\
\hline & GMM & GMM & GMM & GMM & GMM \\
\hline L.lEAprinet_kw & $\begin{array}{l}0.854 * * * \\
(0.000)\end{array}$ & $\begin{array}{l}0.414 * * * \\
(0.000)\end{array}$ & $\begin{array}{l}0.407 * * * \\
(0.000)\end{array}$ & $\begin{array}{l}0.428 * * * \\
(0.000)\end{array}$ & $\begin{array}{l}0.414^{* * *} \\
(0.000)\end{array}$ \\
\hline ER & $\begin{array}{l}0.003 \\
(0.690)\end{array}$ & & & & \\
\hline ERpo_d & & $\begin{array}{l}-0.376^{* * *} \\
(0.000)\end{array}$ & $\begin{array}{l}-0.356^{* * *} \\
(0.000)\end{array}$ & $\begin{array}{l}-0.350 * * * \\
(0.000)\end{array}$ & $\begin{array}{l}-0.366^{* * *} \\
(0.000)\end{array}$ \\
\hline ERen_d & & $\begin{array}{l}-0.106^{*} \\
(0.072)\end{array}$ & & & \\
\hline ERvi_d & & $\begin{array}{l}0.099 \\
(0.233)\end{array}$ & $\begin{array}{l}0.079 \\
(0.393)\end{array}$ & $\begin{array}{l}0.037 \\
(0.598)\end{array}$ & $\begin{array}{l}0.066 \\
(0.462)\end{array}$ \\
\hline ERen1_d & & & $\begin{array}{l}-0.043 \\
(0.483)\end{array}$ & & \\
\hline ERen2_d & & & $\begin{array}{l}-0.015 \\
(0.741)\end{array}$ & & $\begin{array}{l}-0.024 \\
(0.596)\end{array}$ \\
\hline ERen3_d & & & $\begin{array}{l}-0.098 * \\
(0.073)\end{array}$ & $\begin{array}{l}-0.100 * * \\
(0.049)\end{array}$ & $\begin{array}{l}-0.092 * \\
(0.088)\end{array}$ \\
\hline lEAscmbf & $\begin{array}{l}0.025^{* *} \\
(0.011)\end{array}$ & $\begin{array}{l}0.016 \\
(0.517)\end{array}$ & $\begin{array}{l}0.021 \\
(0.408)\end{array}$ & $\begin{array}{l}0.023 \\
(0.354)\end{array}$ & $\begin{array}{l}0.021 \\
(0.409)\end{array}$ \\
\hline lEAimports & $\begin{array}{l}0.000 \\
(0.720)\end{array}$ & $\begin{array}{l}-0.000 \\
(0.913)\end{array}$ & $\begin{array}{l}-0.000 \\
(0.900)\end{array}$ & $\begin{array}{l}-0.000 \\
(0.936)\end{array}$ & $\begin{array}{l}-0.000 \\
(0.917)\end{array}$ \\
\hline lEArescons & $\begin{array}{l}-0.022 * * \\
(0.012)\end{array}$ & $\begin{array}{l}0.002 \\
(0.948)\end{array}$ & $\begin{array}{l}-0.008 \\
(0.805)\end{array}$ & $\begin{array}{l}-0.007 \\
(0.820)\end{array}$ & $\begin{array}{l}-0.005 \\
(0.870)\end{array}$ \\
\hline lMWgdppc & $\begin{array}{l}0.016 \\
(0.274)\end{array}$ & $\begin{array}{l}0.231^{* * *} \\
(0.000)\end{array}$ & $\begin{array}{l}0.215^{* * *} \\
(0.000)\end{array}$ & $\begin{array}{l}0.225^{* * *} \\
(0.000)\end{array}$ & $\begin{array}{l}0.227 * * * \\
(0.000)\end{array}$ \\
\hline Year fixed-effects & yes & yes & yes & yes & yes \\
\hline Constant & $\begin{array}{l}-0.292 * * \\
(0.026)\end{array}$ & $\begin{array}{l}-0.676^{* *} \\
(0.011)\end{array}$ & $\begin{array}{l}-0.683 * * \\
(0.011)\end{array}$ & $\begin{array}{l}-0.612^{* *} \\
(0.015)\end{array}$ & $\begin{array}{l}-0.647^{* *} \\
(0.014)\end{array}$ \\
\hline Observations & 402 & 402 & 402 & 402 & 402 \\
\hline ar1p & 0.001 & 0.052 & 0.055 & 0.037 & 0.047 \\
\hline ar2p & 0.281 & 0.952 & 0.733 & 0.735 & 0.787 \\
\hline Number of country & 15 & 15 & 15 & 15 & 15 \\
\hline sarganp & 0.064 & 0.257 & 0.201 & 0.188 & 0.205 \\
\hline N. instr. & 98 & 85 & 85 & 85 & 85 \\
\hline
\end{tabular}

Dep. var.: log average price for electricity supply

Source: Authors' calculations using IEA, WDI source data. IEA data used for price series. For exact source and variable definition refer to the label (in italics in the first column) and Table 6.

Notes: Robust p-values in parentheses. ${ }^{* * *} \mathrm{p}<0.01,{ }^{* *} \mathrm{p}<0.05,{ }^{*} \mathrm{p}<0.1$. Year dummies included in all models.

ar1p and ar2p report the p-values of tests for first-order and second-order serial correlation, asymptically $\mathrm{N}(0,1)$ under the null of no autocorrelation.

GMM results are one-step estimates with heteroskedasticity-consistent standard errors (in parentheses) and test statistics.

Instruments used in all GMM equations include dependent variable at lags $\mathrm{t}-3, \mathrm{t}-4, \mathrm{t}-5$, the predetermined regulatory variable (at time $\mathrm{t}-1$ and earlier) and exogenous variables. 


\section{Table 8: GMM estimation of dynamic panels for gas prices.}

\begin{tabular}{|c|c|c|c|c|c|}
\hline & (1) & (2) & (3) & (4) & (5) \\
\hline & GMM & GMM & GMM & GMM & GMM \\
\hline \multirow[t]{2}{*}{ L.lGAprinet_gj } & $0.712 * * *$ & $0.806^{* * *}$ & $0.795 * * *$ & $0.797 * * *$ & $0.811 * * *$ \\
\hline & $(0.000)$ & $(0.000)$ & $(0.000)$ & $(0.000)$ & $(0.000)$ \\
\hline \multirow[t]{2}{*}{ GR } & $-0.094 * *$ & & & & \\
\hline & $(0.027)$ & & & & \\
\hline \multirow[t]{2}{*}{ GRpo_d } & & $-0.240 * * *$ & $-0.233 * *$ & $-0.227 * *$ & $-0.245 * * *$ \\
\hline & & $(0.007)$ & $(0.015)$ & $(0.017)$ & $(0.008)$ \\
\hline \multirow[t]{2}{*}{ GRvi_d } & & -0.025 & -0.016 & -0.013 & -0.030 \\
\hline & & $(0.691)$ & $(0.811)$ & $(0.840)$ & $(0.614)$ \\
\hline \multirow[t]{2}{*}{ GRen_d } & & -0.028 & & & \\
\hline & & $(0.726)$ & & & \\
\hline \multirow[t]{2}{*}{ GRen1_d } & & & 0.047 & & \\
\hline & & & $(0.509)$ & & \\
\hline \multirow[t]{2}{*}{ GRen2_d } & & & -0.073 & -0.043 & \\
\hline & & & $(0.402)$ & $(0.564)$ & \\
\hline \multirow[t]{2}{*}{ GRen3_d } & & & -0.019 & -0.005 & -0.020 \\
\hline & & & $(0.900)$ & $(0.974)$ & $(0.890)$ \\
\hline \multirow[t]{2}{*}{ lGAbrent } & 0.025 & $0.076^{* *}$ & $0.082 * *$ & $0.071 *$ & $0.072 *$ \\
\hline & $(0.591)$ & $(0.028)$ & $(0.041)$ & $(0.053)$ & $(0.052)$ \\
\hline Year fixed-effects & yes & yes & yes & yes & yes \\
\hline \multirow[t]{2}{*}{ Constant } & $0.843^{* *}$ & 0.220 & 0.231 & 0.268 & 0.229 \\
\hline & $(0.048)$ & $(0.240)$ & $(0.417)$ & $(0.340)$ & $(0.405)$ \\
\hline Observations & 295 & 295 & 295 & 295 & 295 \\
\hline Number of country & 11 & 11 & 11 & 11 & 11 \\
\hline $\operatorname{ar1p}$ & 0.029 & 0.019 & 0.013 & 0.015 & 0.017 \\
\hline ar2p & 0.561 & 0.392 & 0.499 & 0.486 & 0.430 \\
\hline sarganp & 0.318 & 0.496 & 0.383 & 0.428 & 0.498 \\
\hline N. instr. & 83 & 83 & 83 & 83 & 83 \\
\hline
\end{tabular}

Dep. var.: log average price for gas supply.

Source: Authors' calculations using IEA, WDI source data. IEA data used for price series. For exact source and variable definition refer to the label (in italics in the first column) and Table 6

Notes: Robust p-values in parentheses. ${ }^{* * *} \mathrm{p}<0.01,{ }^{*} \mathrm{p}<0.05, * \mathrm{p}<0.1$. Year dummies included in all models.

ar1p and ar2p report the p-values of tests for first-order and second-order serial correlation, asymptically $\mathrm{N}(0,1)$ under the null of no autocorrelation.

GMM results are one-step estimates with heteroskedasticity-consistent standard errors (in parentheses) and test statistics.

Instruments used in all GMM equations include dependent variable at lags $\mathrm{t}-3, \mathrm{t}-4, \mathrm{t}-5$, the predetermined regulatory variable (at time t-1 and earlier) and exogenous variables. 
Table 9: Robustness checks for the electricity price model. Dynamic panel estimated using OLS and Withind methods.

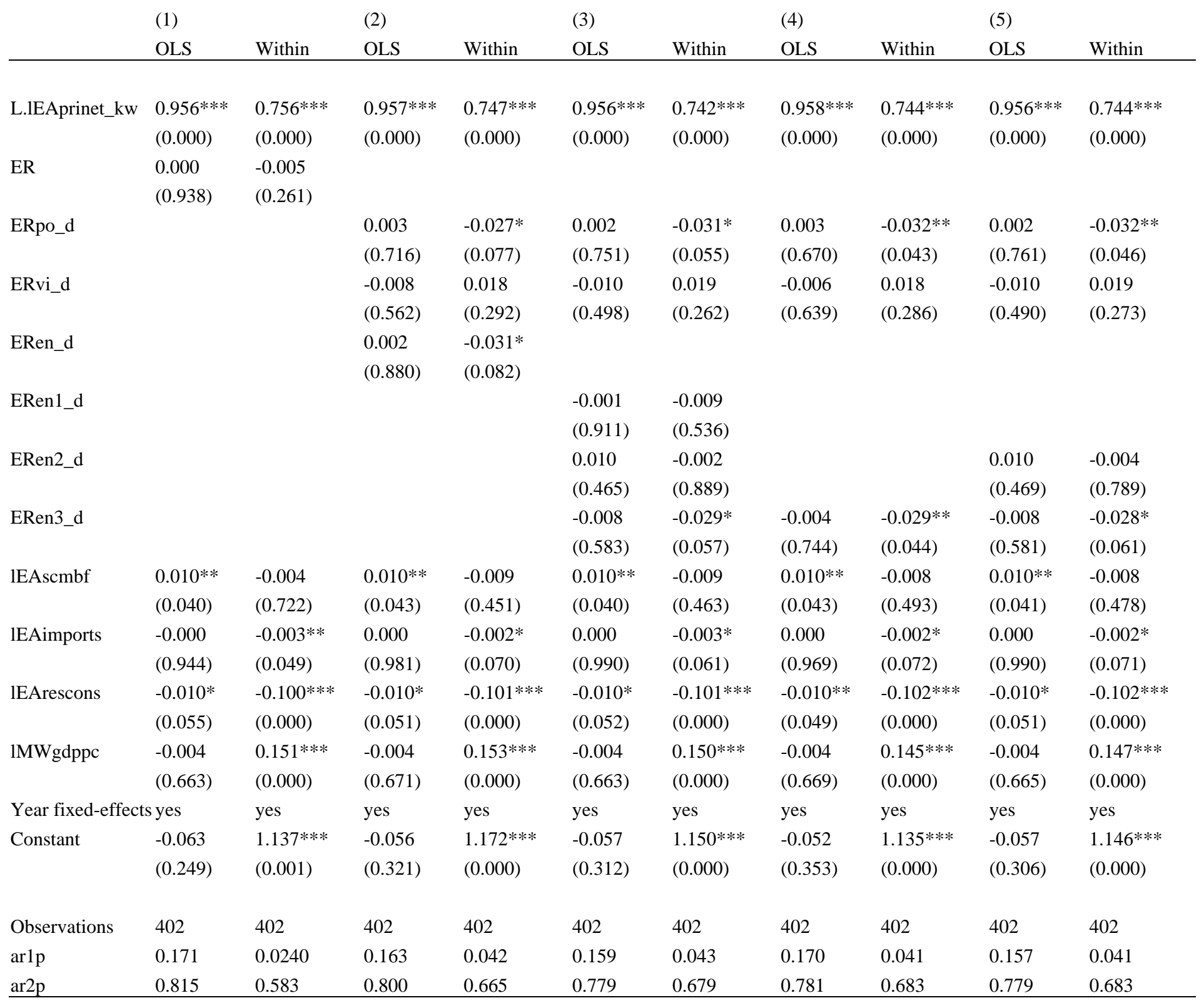

Dep. var.: $\log$ average price for electricity supply. Robust $\mathrm{p}$-values in parenthesis. ${ }^{* * *} \mathrm{p}<0.01,{ }^{* *} \mathrm{p}<0.05,{ }^{*} \mathrm{p}<0.1$. Legend: see Table 7 . 
Table 10: Robustness checks for the gas price model. Dynamic panel estimated using OLS and Withind methods.

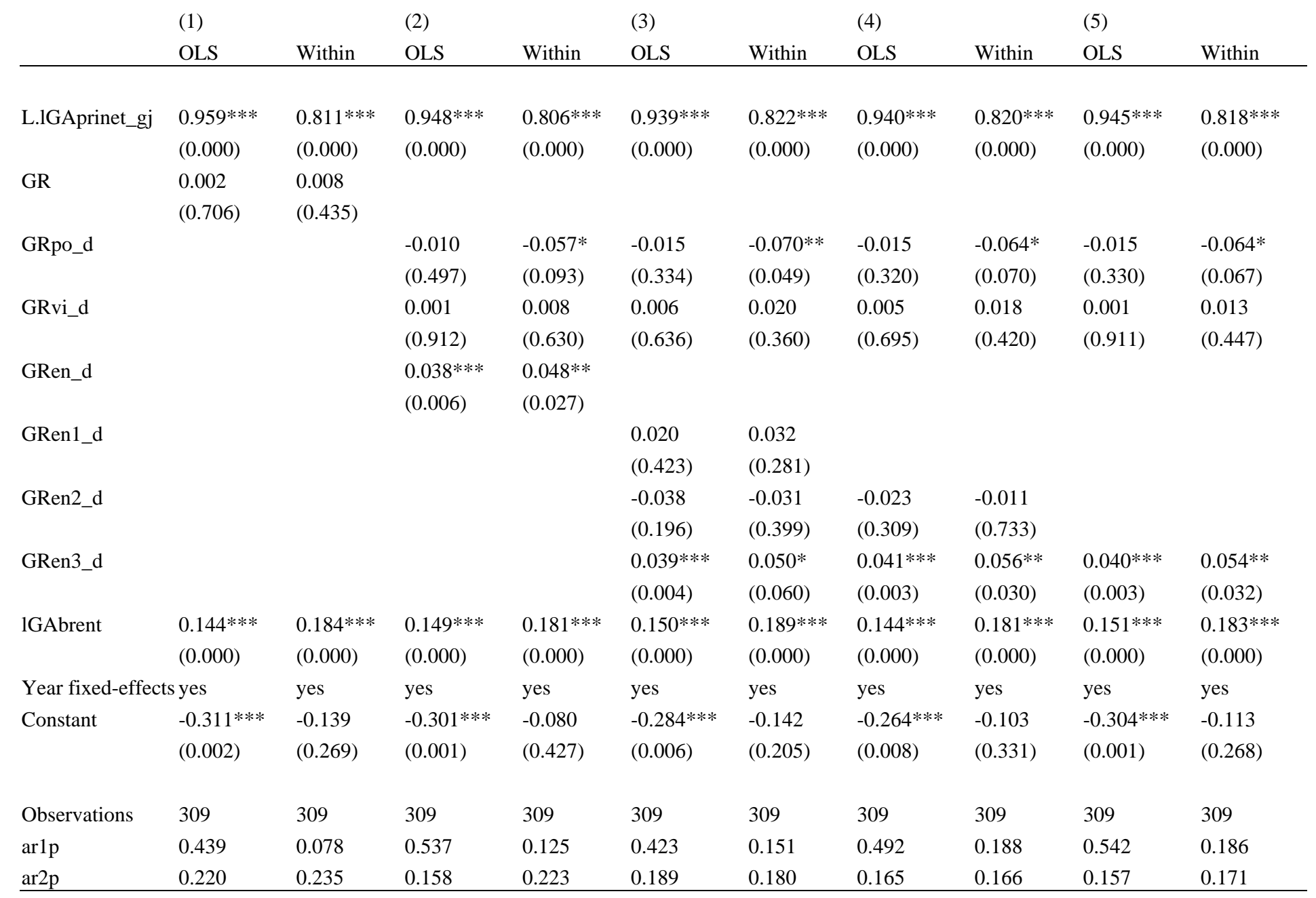

Dep. var.: average price for gas supply. Robust $\mathrm{p}$-values in parenthesis. ${ }^{* * *} \mathrm{p}<0.01,{ }^{* *} \mathrm{p}<0.05,{ }^{*} \mathrm{p}<0.1$. Legend: see Table 8 . 
Table 11: Robustness checks of GMM models of average price for electricity.

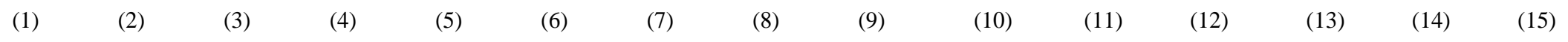
excluded country belgium denmark germany greece italy spain france ireland luxembourg netherlands portugal great britain finland sweden austria

\begin{tabular}{|c|c|c|c|c|c|c|c|c|c|c|c|c|c|c|c|}
\hline L.lEAprinet_kw & $\begin{array}{l}0.420 * * * \\
(0.000)\end{array}$ & $\begin{array}{l}0.533 * * * \\
(0.000)\end{array}$ & $\begin{array}{l}0.441 * * * \\
(0.000)\end{array}$ & $\begin{array}{l}0.438 * * * \\
(0.000)\end{array}$ & $\begin{array}{l}0.296 * * * \\
(0.007)\end{array}$ & $\begin{array}{l}0.466 * * * \\
(0.000)\end{array}$ & $\begin{array}{l}0.465 * * * \\
(0.000)\end{array}$ & $\begin{array}{l}0.443^{* * *} \\
(0.000)\end{array}$ & $\begin{array}{l}0.438 * * * \\
(0.000)\end{array}$ & $\begin{array}{l}0.416^{* * *} \\
(0.000)\end{array}$ & $\begin{array}{l}0.211^{* *} \\
(0.036)\end{array}$ & $\begin{array}{l}0.384 * * * \\
(0.000)\end{array}$ & $\begin{array}{l}0.367 * * * \\
(0.001)\end{array}$ & $\begin{array}{l}0.453 * * * \\
(0.000)\end{array}$ & $\begin{array}{l}0.510 * * * \\
(0.000)\end{array}$ \\
\hline ERpo_d & $\begin{array}{l}-0.373^{* * *} \\
(0.000)\end{array}$ & $\begin{array}{l}-0.225^{* * *} \\
(0.000)\end{array}$ & $\begin{array}{l}-0.335^{* * *} \\
(0.000)\end{array}$ & $\begin{array}{l}-0.477 * * * \\
(0.000)\end{array}$ & $\begin{array}{l}-0.432^{* * *} \\
(0.000)\end{array}$ & $\begin{array}{l}-0.337^{* * *} \\
(0.000)\end{array}$ & $\begin{array}{l}-0.350 * * * \\
(0.000)\end{array}$ & $\begin{array}{l}-0.370 * * * \\
(0.000)\end{array}$ & $\begin{array}{l}-0.353^{* * *} \\
(0.000)\end{array}$ & $\begin{array}{l}-0.374^{* * *} \\
(0.000)\end{array}$ & $\begin{array}{l}-0.266^{* * *} \\
(0.000)\end{array}$ & $\begin{array}{l}-0.351^{* * *} \\
(0.000)\end{array}$ & $\begin{array}{l}-0.356 * * * \\
(0.000)\end{array}$ & $\begin{array}{l}-0.355^{* * * *} \\
(0.000)\end{array}$ & $\begin{array}{l}-0.230 * * * \\
(0.000)\end{array}$ \\
\hline ERen_d & $\begin{array}{l}-0.106 * \\
(0.080)\end{array}$ & $\begin{array}{l}-0.055 \\
(0.239)\end{array}$ & $\begin{array}{l}-0.084 \\
(0.157)\end{array}$ & $\begin{array}{l}-0.065 \\
(0.279)\end{array}$ & $\begin{array}{l}-0.175^{* * *} \\
(0.003)\end{array}$ & $\begin{array}{l}-0.097 * \\
(0.091)\end{array}$ & $\begin{array}{l}-0.070 \\
(0.203)\end{array}$ & $\begin{array}{l}-0.086 \\
(0.138)\end{array}$ & $\begin{array}{l}-0.041 \\
(0.537)\end{array}$ & $\begin{array}{l}-0.099 * \\
(0.098)\end{array}$ & $\begin{array}{l}0.017 \\
(0.765)\end{array}$ & $\begin{array}{l}-0.093^{*} \\
(0.097)\end{array}$ & $\begin{array}{l}-0.148^{* *} \\
(0.025)\end{array}$ & $\begin{array}{l}-0.083 \\
(0.225)\end{array}$ & $\begin{array}{l}-0.076 \\
(0.172)\end{array}$ \\
\hline ERvi_d & $\begin{array}{l}0.106 \\
(0.216)\end{array}$ & $\begin{array}{l}0.041 \\
(0.420)\end{array}$ & $\begin{array}{l}0.083 \\
(0.302)\end{array}$ & $\begin{array}{l}0.121 \\
(0.171)\end{array}$ & $\begin{array}{l}0.104 \\
(0.244)\end{array}$ & $\begin{array}{l}0.037 \\
(0.521)\end{array}$ & $\begin{array}{l}0.062 \\
(0.446)\end{array}$ & $\begin{array}{l}0.062 \\
(0.453)\end{array}$ & $\begin{array}{l}-0.045 \\
(0.637)\end{array}$ & $\begin{array}{l}0.105 \\
(0.188)\end{array}$ & $\begin{array}{l}0.049 \\
(0.501)\end{array}$ & $\begin{array}{l}-0.164 \\
(0.173)\end{array}$ & $\begin{array}{l}0.126 \\
(0.137)\end{array}$ & $\begin{array}{l}0.084 \\
(0.328)\end{array}$ & $\begin{array}{l}-0.041 \\
(0.501)\end{array}$ \\
\hline EAscmbf & $\begin{array}{l}0.017 \\
(0.514)\end{array}$ & $\begin{array}{l}0.037 \\
(0.102)\end{array}$ & $\begin{array}{l}0.018 \\
(0.470)\end{array}$ & $\begin{array}{l}-0.006 \\
(0.831)\end{array}$ & $\begin{array}{l}0.002 \\
(0.932)\end{array}$ & $\begin{array}{l}0.020 \\
(0.425)\end{array}$ & $\begin{array}{l}0.020 \\
(0.439)\end{array}$ & $\begin{array}{l}0.020 \\
(0.429)\end{array}$ & $\begin{array}{l}0.004 \\
(0.913)\end{array}$ & $\begin{array}{l}0.021 \\
(0.404)\end{array}$ & $\begin{array}{l}0.043^{* *} \\
(0.044)\end{array}$ & $\begin{array}{l}0.029 \\
(0.247)\end{array}$ & $\begin{array}{l}0.012 \\
(0.658)\end{array}$ & $\begin{array}{l}0.008 \\
(0.759)\end{array}$ & $\begin{array}{l}0.027 \\
(0.253)\end{array}$ \\
\hline lEAimports & $\begin{array}{l}-0.000 \\
(0.930)\end{array}$ & $\begin{array}{l}-0.001 \\
(0.808)\end{array}$ & $\begin{array}{l}0.000 \\
(1.000)\end{array}$ & $\begin{array}{l}-0.000 \\
(0.895)\end{array}$ & $\begin{array}{l}-0.001 \\
(0.667)\end{array}$ & $\begin{array}{l}0.000 \\
(0.969)\end{array}$ & $\begin{array}{l}0.001 \\
(0.862)\end{array}$ & $\begin{array}{l}-0.000 \\
(0.921)\end{array}$ & $\begin{array}{l}0.001 \\
(0.773)\end{array}$ & $\begin{array}{l}-0.001 \\
(0.830)\end{array}$ & $\begin{array}{l}01 \\
18)\end{array}$ & $\begin{array}{l}0.001 \\
(0.859)\end{array}$ & $\begin{array}{l}-0.001 \\
(0.819)\end{array}$ & $\begin{array}{l}-0.000 \\
(0.958)\end{array}$ & $\begin{array}{l}0.001 \\
(0.835)\end{array}$ \\
\hline EArescons & $\begin{array}{l}0.002 \\
(0.950)\end{array}$ & $\begin{array}{l}-0.019 \\
(0.463)\end{array}$ & $\begin{array}{l}-0.000 \\
(0.997)\end{array}$ & $\begin{array}{l}0.039 \\
(0.273)\end{array}$ & $\begin{array}{l}-0.001 \\
(0.977)\end{array}$ & $\begin{array}{l}-0.011 \\
(0.705)\end{array}$ & $\begin{array}{l}-0.003 \\
(0.915)\end{array}$ & $\begin{array}{l}-0.010 \\
(0.750)\end{array}$ & $\begin{array}{l}-0.078 \\
(0.145)\end{array}$ & $\begin{array}{l}-0.003 \\
(0.917)\end{array}$ & $\begin{array}{l}0.023 \\
(0.385)\end{array}$ & $\begin{array}{l}-0.017 \\
(0.558)\end{array}$ & $\begin{array}{l}0.007 \\
(0.817)\end{array}$ & $\begin{array}{l}0.012 \\
(0.698)\end{array}$ & $\begin{array}{l}-0.025 \\
(0.362)\end{array}$ \\
\hline MWgdppc & $\begin{array}{l}0.230 * * * \\
(0.000)\end{array}$ & $\begin{array}{l}0.213 * * * \\
(0.000)\end{array}$ & $\begin{array}{l}0.221^{* * * *} \\
(0.000)\end{array}$ & $\begin{array}{l}0.239 * * * \\
(0.000)\end{array}$ & $\begin{array}{l}0.236 * * * \\
(0.000)\end{array}$ & $\begin{array}{l}0.208 * * * \\
(0.000)\end{array}$ & $\begin{array}{l}0.232 * * * \\
(0.000)\end{array}$ & $\begin{array}{l}0.207^{* * *} \\
(0.000)\end{array}$ & $\begin{array}{l}0.283^{* * *} \\
(0.000)\end{array}$ & $\begin{array}{l}0.229 * * * \\
(0.000)\end{array}$ & $\begin{array}{l}0.397 * * * \\
(0.000)\end{array}$ & $\begin{array}{l}0.196 * * * \\
(0.000)\end{array}$ & $\begin{array}{l}0.245^{* * *} \\
(0.000)\end{array}$ & $\begin{array}{l}0.224 * * * \\
(0.000)\end{array}$ & $\begin{array}{l}0.202 * * * \\
(0.000)\end{array}$ \\
\hline Year fixed-effects & yes & yes & yes & yes & yes & yes & yes & yes & yes & yes & yes & yes & & & \\
\hline Constant & $\begin{array}{l}-0.678 * * \\
(0.013)\end{array}$ & $\begin{array}{l}-0.484 * * \\
(0.028)\end{array}$ & $\begin{array}{l}-0.657 * * \\
(0.011)\end{array}$ & $\begin{array}{l}-0.710 * * \\
(0.013)\end{array}$ & $\begin{array}{l}-0.728 * * \\
(0.013)\end{array}$ & $\begin{array}{l}-0.529 * * \\
(0.028)\end{array}$ & $\begin{array}{l}-0.529 * * \\
(0.035)\end{array}$ & $\begin{array}{l}-0.627 * * \\
(0.021)\end{array}$ & $\begin{array}{l}0.593 \\
(0.248)\end{array}$ & $\begin{array}{l}-0.718 * * * \\
(0.009)\end{array}$ & $\begin{array}{l}-1.130 * * * \\
(0.000)\end{array}$ & $\begin{array}{l}-0.681 * * * \\
(0.009)\end{array}$ & $\begin{array}{l}-0.718 * * * \\
(0.006)\end{array}$ & $\begin{array}{l}-0.621 * * \\
(0.021)\end{array}$ & $\begin{array}{l}-0.351 \\
(0.119)\end{array}$ \\
\hline Observations & 380 & 375 & 374 & 375 & 374 & 375 & 374 & 374 & 374 & 374 & 374 & 374 & 374 & 383 & 374 \\
\hline ar1p & 0.056 & 0.042 & 0.049 & 0.073 & 0.078 & 0.036 & 0.041 & 0.033 & 0.072 & 0.052 & 0.219 & 0.110 & 0.057 & 0.042 & 0.038 \\
\hline ar2p & 0.934 & 0.842 & 0.966 & 0.760 & 0.341 & 0.756 & 0.950 & 0.908 & 0.759 & 0.781 & 0.549 & 0.153 & 0.851 & 0.840 & 0.681 \\
\hline Number of country & 14 & 14 & 14 & 14 & 14 & 14 & 14 & 14 & 14 & 14 & 14 & 14 & 14 & 14 & 14 \\
\hline sarganp & 0.358 & 0.393 & 0.211 & 0.437 & 0.526 & 0.218 & 0.0478 & 0.290 & 0.334 & 0.360 & 0.0844 & 0.364 & 0.233 & 0.211 & 0.00890 \\
\hline N. instr. & 85 & 85 & 85 & 84 & 84 & 85 & 85 & 85 & 84 & 85 & 84 & 84 & 85 & 85 & 85 \\
\hline
\end{tabular}

Dep. var.: $\log$ average price for electricity supply. Robust $\mathrm{p}$-values in parenthesis. ${ }^{* * *} \mathrm{p}<0.01,{ }^{* *} \mathrm{p}<0.05,{ }^{*} \mathrm{p}<0.1$. Legend: see Table 7. 
Table 12: Robustness checks of GMM models of average price for gas supply.

\begin{tabular}{|c|c|c|c|c|c|c|c|c|c|c|c|}
\hline & (1) & (2) & (3) & (4) & (5) & (6) & (7) & (8) & (9) & (10) & (12) \\
\hline escluded country & belgium & denmark & germany & spain & france & ireland & luxembourg & netherlands & great britain & finland & austria \\
\hline L.lGAprinet_gj & $\begin{array}{l}0.790 * * * \\
(0.000)\end{array}$ & $\begin{array}{l}0.784 * * * \\
(0.000)\end{array}$ & $\begin{array}{l}0.796 * * * \\
(0.000)\end{array}$ & $\begin{array}{l}0.826 * * * \\
(0.000)\end{array}$ & $\begin{array}{l}0.804^{* * *} \\
(0.000)\end{array}$ & $\begin{array}{l}0.777 * * * \\
(0.000)\end{array}$ & $\begin{array}{l}0.808 * * * \\
(0.000)\end{array}$ & $\begin{array}{l}0.777 * * * \\
(0.000)\end{array}$ & $\begin{array}{l}0.854 * * * \\
(0.000)\end{array}$ & $\begin{array}{l}0.719 * * * \\
(0.000)\end{array}$ & $\begin{array}{l}0.790 * * * \\
(0.000)\end{array}$ \\
\hline GRpo_d & $\begin{array}{l}-0.231^{* * *} \\
(0.010)\end{array}$ & $\begin{array}{l}-0.455^{* * *} \\
(0.008)\end{array}$ & $\begin{array}{l}-0.235^{* * *} \\
(0.009)\end{array}$ & $\begin{array}{l}-0.256^{* * *} \\
(0.007)\end{array}$ & $\begin{array}{l}-0.249 * * * \\
(0.008)\end{array}$ & $\begin{array}{l}-0.282^{* * *} \\
(0.001)\end{array}$ & $\begin{array}{l}-0.243^{* * *} \\
(0.003)\end{array}$ & $\begin{array}{l}-0.203^{* *} \\
(0.016)\end{array}$ & $\begin{array}{l}-0.141 \\
(0.169)\end{array}$ & $\begin{array}{l}-0.192 * * * \\
(0.010)\end{array}$ & $\begin{array}{l}-0.252^{* * *} \\
(0.005)\end{array}$ \\
\hline GRvi_d & $\begin{array}{l}-0.020 \\
(0.746)\end{array}$ & $\begin{array}{l}-0.058 \\
(0.258)\end{array}$ & $\begin{array}{l}-0.017 \\
(0.796)\end{array}$ & $\begin{array}{l}-0.025 \\
(0.720)\end{array}$ & $\begin{array}{l}-0.033 \\
(0.600)\end{array}$ & $\begin{array}{l}0.006 \\
(0.926)\end{array}$ & $\begin{array}{l}-0.044 \\
(0.468)\end{array}$ & $\begin{array}{l}-0.022 \\
(0.712)\end{array}$ & $\begin{array}{l}0.012 \\
(0.837)\end{array}$ & $\begin{array}{l}-0.075 \\
(0.286)\end{array}$ & $\begin{array}{l}-0.015 \\
(0.811)\end{array}$ \\
\hline GRen_d & $\begin{array}{l}-0.028 \\
(0.728)\end{array}$ & $\begin{array}{l}-0.027 \\
(0.724)\end{array}$ & $\begin{array}{l}-0.036 \\
(0.660)\end{array}$ & $\begin{array}{l}-0.045 \\
(0.657)\end{array}$ & $\begin{array}{l}-0.016 \\
(0.833)\end{array}$ & $\begin{array}{l}-0.077 \\
(0.378)\end{array}$ & $\begin{array}{l}-0.018 \\
(0.829)\end{array}$ & $\begin{array}{l}-0.040 \\
(0.625)\end{array}$ & $\begin{array}{l}-0.018 \\
(0.832)\end{array}$ & $\begin{array}{l}-0.052 \\
(0.486)\end{array}$ & $\begin{array}{l}-0.031 \\
(0.689)\end{array}$ \\
\hline lGAbrent & $\begin{array}{l}0.080 * * \\
(0.028)\end{array}$ & $\begin{array}{l}0.070 * * \\
(0.026)\end{array}$ & $\begin{array}{l}0.081 * * \\
(0.031)\end{array}$ & $\begin{array}{l}0.061 \\
(0.132)\end{array}$ & $\begin{array}{l}0.106^{* * *} \\
(0.004)\end{array}$ & $\begin{array}{l}0.063 * \\
(0.071)\end{array}$ & $\begin{array}{l}0.071^{* *} \\
(0.039)\end{array}$ & $\begin{array}{l}0.084 * * \\
(0.030)\end{array}$ & $\begin{array}{l}0.089 * * \\
(0.029)\end{array}$ & $\begin{array}{l}0.085^{* * *} \\
(0.008)\end{array}$ & $\begin{array}{l}0.067^{*} \\
(0.068)\end{array}$ \\
\hline Year fixed-effects & yes & yes & yes & yes & yes & yes & yes & yes & yes & yes & yes \\
\hline Constant & $\begin{array}{l}0.242 \\
(0.218)\end{array}$ & $\begin{array}{l}0.327 * \\
(0.063)\end{array}$ & $\begin{array}{l}0.229 \\
(0.242)\end{array}$ & $\begin{array}{l}0.227 \\
(0.322)\end{array}$ & $\begin{array}{l}0.124 \\
(0.457)\end{array}$ & $\begin{array}{l}0.285 \\
(0.106)\end{array}$ & $\begin{array}{l}0.252 \\
(0.178)\end{array}$ & $\begin{array}{l}0.253 \\
(0.199)\end{array}$ & $\begin{array}{l}0.050 \\
(0.798)\end{array}$ & $\begin{array}{l}0.409 * \\
(0.054)\end{array}$ & $\begin{array}{l}0.280 \\
(0.154)\end{array}$ \\
\hline Observations & 273 & 274 & 273 & 266 & 266 & 266 & 267 & 266 & 266 & 266 & 267 \\
\hline Number of country & 10 & 10 & 10 & 10 & 10 & 10 & 10 & 10 & 10 & 10 & 10 \\
\hline $\operatorname{ar1p}$ & 0.020 & 0.014 & 0.020 & 0.018 & 0.020 & 0.023 & 0.030 & 0.023 & 0.029 & 0.031 & 0.025 \\
\hline ar2p & 0.367 & 0.771 & 0.372 & 0.270 & 0.394 & 0.190 & 0.286 & 0.485 & 0.705 & 0.305 & 0.422 \\
\hline sarganp & 0.568 & 0.528 & 0.654 & 0.646 & 0.568 & 0.131 & 0.883 & 0.597 & 0.480 & 0.243 & 0.432 \\
\hline N. instr. & 83 & 82 & 83 & 83 & 82 & 83 & 83 & 83 & 82 & 83 & 83 \\
\hline
\end{tabular}

Dep. var.: $\log$ average price for electricity supply. Robust $\mathrm{p}$-values in parenthesis. ${ }^{* * *} \mathrm{p}<0.01,{ }^{* *} \mathrm{p}<0.05,{ }^{*} \mathrm{p}<0.1$. Legend: see Table 8 . 


\section{Appendix}

Here, we provide some evidence supporting the assumption that $\alpha \neq 0$, using notation introduced in Section 5. In case (log) prices did not follow an autoregressive process, one would not need to use the dynamic panel toolkit for dealing with the endogeneity of the lagged dependent variable and, standard Within group transformation would be enough to sweep out the correlation of some regressors with the error term because of the country fixed effect. In other words, what would one lose if model (1) was estimated under the restriction that $\alpha=0$ ? Our approach to answer this question is straightforward and follows Blundell and Bond (2000). First of all we estimate simple AR(1) equations of (log) prices for each sector separately, including year dummies in all models using OLS and Within estimation methods. Table A1 presents results. It shows that in all models the lagged dependent variable is highly statistically significant, with a p-value smaller than $0.1 \%$ and with a large but statistically smaller than one coefficient. $^{15}$ This supports our expectations that the lagged dependent variable is a relevant variable to include in the analysis.

However, as the main focus of our paper are the coefficients in vector $\beta$, we are mostly interested to assess whether the omission of $P_{t-1}$ would bias its estimation. This would happen if $P_{i, t-1}$ was correlated with the regulatory variables. Hence, we regress the one-period-lagged log prices first over the sector score (0-6) and a full set of time-dummies and test whether the coefficient of the sector score is significantly different from zero. Then we do the same replacing the sector score with the set of regulatory dummies (0-1), which we then use in our empirical investigation (Section 0) and perform an F-test of the hypothesis that all coefficients of the regulatory dummies are jointly zero. Results are shown in Table A 2, where the relevant test statistics on the regulatory variables' coefficients is named F1. The p-values of these tests let us conclude that the correlation is highly significant in all specifications, except for the ETCR score variable in the gas sector. In other words, except for this case, we conclude that dynamic panel models are necessary for avoiding omitted variable bias in the $\beta$ coefficients. ${ }^{16}$

\footnotetext{
${ }^{15}$ We also estimated AR(2) processes but found no clear evidence on the significance of the coefficient of the two-period lagged dependent variable, so we ruled out the possibility of using longer lags of (log) prices among regressors.

${ }^{16}$ Nonetheless, we estimate dynamic panels also in the model of gas prices with ECTR score variable for consistency with other models specification.
} 


\section{Table A1: AR(1) specification for the series of price by sector.}

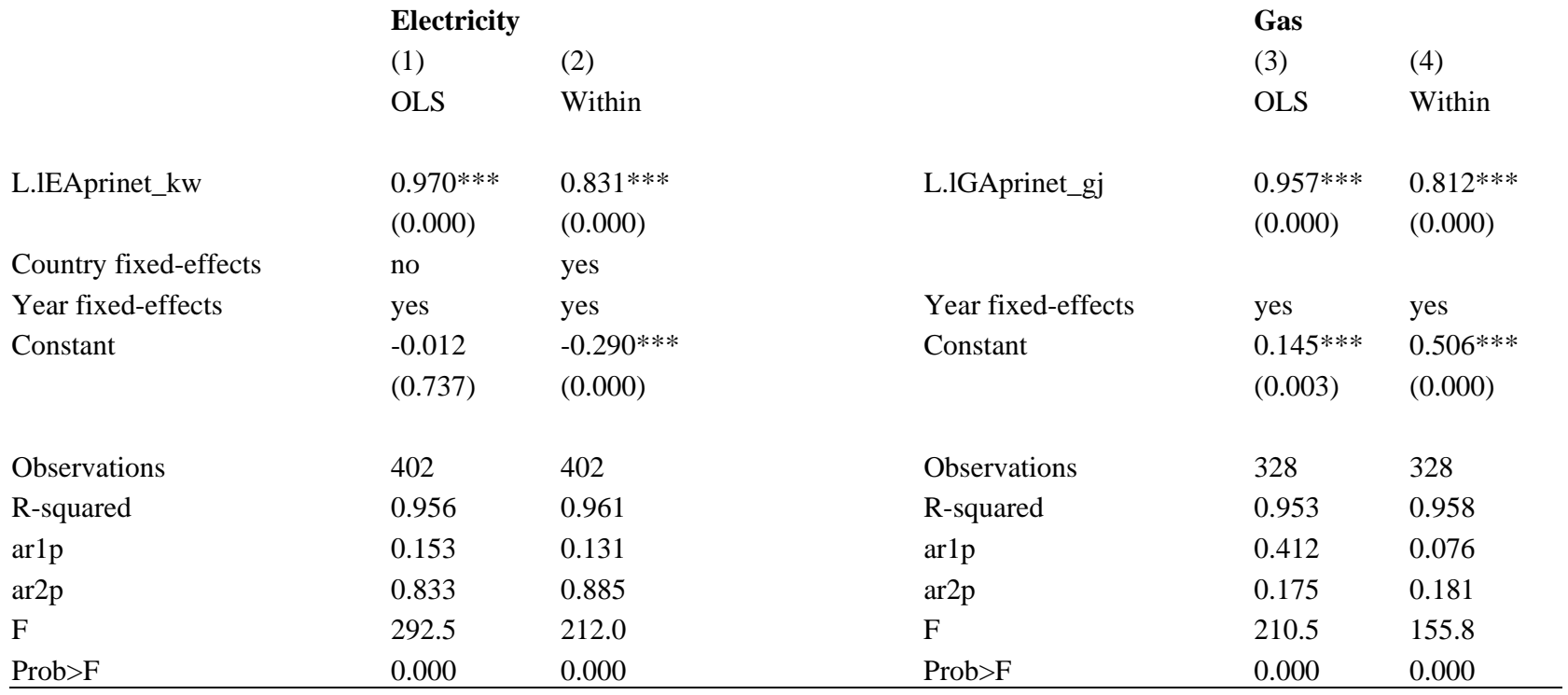

Source: Authors' calculations using IEA data.

Notes: The price models estimated are simple AR(1) models where the dependent variable (log average price) is regressed over its value lagged one period, and year dummies. Models are estimated separately for each sector. The dependent variable is sector's log average price, i.e. IEAprinet_kw and lGAprinet_gj, for electricity and gas, respectively. For variable definitions and sources, refer toTable 2 and Table 3.

Robust p-values in parentheses. ${ }^{* * *} \mathrm{p}<0.01, * * \mathrm{p}<0.05, * \mathrm{p}<0.1$. Asymptotic standard erros in parentheses.

ar1p and ar2p report the $\mathrm{p}$-values of tests for first-order and second-order serial correlation, which is asymptotically $\mathrm{N}(0,1) \mathrm{under}$ the null of zero correlation. 
Table A 2: An analysis of the omitted lagged price bias on regulatory variables.

Electricity

(1) (2)

(3)

(4)

(5)

Dependent variable: average utility price lagged one period

ER

$-0.029 * * *$

(0.006)

ERpo_d

$\begin{array}{llll}-0.135^{* * *} & -0.143^{* * *} & -0.139 * * * & -0.126^{* * *}\end{array}$

$\begin{array}{llll}(0.000) & (0.000) & (0.000) & (0.000)\end{array}$

ERvi_d

$\begin{array}{llll}-0.081 & -0.102 * * & -0.096 * & -0.020\end{array}$

$\begin{array}{llll}(0.111) & (0.045) \quad(0.059) \quad(0.684)\end{array}$

ERen_d

$$
0.239 * * *
$$

(0.000)

ERen1_d

$$
0.058
$$

(0.211)

ERen2_d

$$
0.189 * * * \quad 0.206^{* * *}
$$$$
(0.000) \quad(0.000)
$$

ERen3_d

$0.028 \quad 0.030 \quad 0.108^{* *}$

(0.573) (0.543) (0.021)

Year fixed-effects yes yes yes yes yes

$\begin{array}{llllll}\text { Constant } & -2.181^{* * *} & -2.206^{* * *} & -2.171^{* * *} & -2.177^{* * *} & -2.228^{* * *}\end{array}$

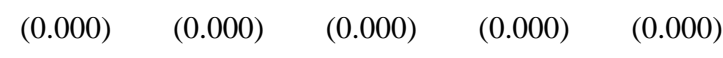

\begin{tabular}{llllll} 
Observations & 405 & 405 & 405 & 405 & 405 \\
R-squared & 0.439 & 0.489 & 0.498 & 0.496 & 0.470 \\
F & 10.520 & 11.935 & 11.522 & 11.825 & 11.075 \\
Prob $>$ F & 0.000 & 0.000 & 0.000 & 0.000 & 0.000 \\
F1 & 7.723 & 14.97 & 10.37 & 12.55 & 10.05 \\
Prob $>$ F1 & 0.006 & 0.000 & 0.000 & 0.000 & 0.000 \\
\hline
\end{tabular}

Source: Authors' calculations using IEA and ETCR source data.
Gas

(6) (7) (8) (9)

Dependent variable: average utility price lagged one period

GR

0.010

(0.636)

GRpo_d

$\begin{array}{llll}0.229^{* * *} & 0.158^{* * *} & 0.156^{* * *} & 0.188^{* * *} \\ (0.000) & (0.002) & (0.002) & (0.000) \\ 0.044 & 0.091^{* *} & 0.083^{* *} & 0.046 \\ (0.293) & (0.030) & (0.046) & (0.264)\end{array}$

GRvi_d

$\begin{array}{llll}(0.293) & (0.030) \quad(0.046) \quad(0.264)\end{array}$

GRen_d

$(0.000)$

GRen1_d 0.131

(0.115)

GRen2_d

$-0.344 * * * \quad-0.246 * * *$

(0.000) (0.000)

GRen3_d

$0.212 * * * \quad 0.225 * * * \quad 0.203 * * *$

$\begin{array}{lll}(0.000) & (0.000) \quad(0.000)\end{array}$

Year fixed-effects yes yes yes yes yes

$\begin{array}{llllll}\text { Constant } & 1.162^{* * *} & 1.013^{* * *} & 1.195^{* * *} & 1.226^{* * *} & 1.006^{* * *}\end{array}$

$\begin{array}{lllll}(0.000) & (0.000) & (0.000) & (0.000) & (0.000)\end{array}$

$\begin{array}{llllll}\text { Observations } & 334 & 334 & 334 & 334 & 334\end{array}$

$\begin{array}{llllll}\text { R-squared } & 0.293 & 0.417 & 0.458 & 0.454 & 0.429\end{array}$

$\begin{array}{llllll}\text { F } & 4.342 & 6.979 & 7.691 & 7.814 & 7.325\end{array}$

$\begin{array}{llllll}\text { Prob }>\mathrm{F} & 0.000 & 0.000 & 0.000 & 0.000 & 0.000\end{array}$

$\begin{array}{llllll}\text { F1 } & 0.225 & 21.59 & 18.38 & 22.23 & 24.13\end{array}$

$\begin{array}{llllll}\text { Prob>F1 } & 0.636 & 0.000 & 0.000 & 0.000 & 0.000\end{array}$

Note: The dependent variable is log average price lagged one period and is estimated separately for each sector. The price variables are lEAprinet_kw and lGAprinet_gj, respectively for the electricity and gas sectors. For variable definitions and sources, refer to Table A1 and Section 5.

The null hypothesis of the F test is that all coefficients are jointly zero.

The null hypothesis of the F1 test is that regulatory variables coefficients are jointly zero. 
Table A 3: Some descriptive statistics for variables used in the price equations.

\begin{tabular}{|c|c|c|c|c|c|}
\hline Variable & Obs & Mean & Std. Dev. & Min & Max \\
\hline \multicolumn{6}{|c|}{ ELECTRICITY } \\
\hline year & 435 & 1992 & 8.38 & 1978 & 2006 \\
\hline EAprinet_kw & 417 & 0.08 & 1.37 & 0.03 & 0.15 \\
\hline ER & 435 & 4.37 & 1.80 & 0.00 & 6.00 \\
\hline ERpo_d & 435 & 0.48 & 0.50 & 0.00 & 1.00 \\
\hline ERen_d & 435 & 0.81 & 0.36 & 0.00 & 1.00 \\
\hline ERvi_d & 435 & 0.91 & 0.28 & 0.00 & 1.00 \\
\hline ERpo_d & 435 & 0.48 & 0.50 & 0.00 & 1.00 \\
\hline ERvi_d & 435 & 0.91 & 0.28 & 0.00 & 1.00 \\
\hline ERen1_d & 435 & 0.66 & 0.47 & 0.00 & 1.00 \\
\hline ERen2_d & 435 & 0.78 & 0.41 & 0.00 & 1.00 \\
\hline ERen3_d & 435 & 0.85 & 0.36 & 0.00 & 1.00 \\
\hline lEAscmbf & 435 & 10.45 & 1.54 & 5.48 & 12.92 \\
\hline lEAimports & 435 & 7.80 & 4.13 & -9.21 & 10.95 \\
\hline lEArescons & 435 & 9.81 & 1.37 & 5.98 & 11.91 \\
\hline MWgdppc & 435 & 0.02 & 1.90 & 0.00 & 0.09 \\
\hline \multicolumn{6}{|c|}{ GAS } \\
\hline year & 321 & 1992 & 8.02 & 1978 & 2006 \\
\hline lGAprinet_gj & 321 & 1.89 & 0.42 & 0.59 & 2.73 \\
\hline GR & 321 & 4.39 & 1.11 & 0.73 & 6.00 \\
\hline GRpo_d & 321 & 0.26 & 0.44 & 0.00 & 1.00 \\
\hline GRen_d & 321 & 0.39 & 0.49 & 0.00 & 1.00 \\
\hline GRms_d & 321 & 0.24 & 0.43 & 0.00 & 1.00 \\
\hline GRvi_d & 321 & 0.50 & 0.50 & 0.00 & 1.00 \\
\hline GRpo_d & 321 & 0.26 & 0.44 & 0.00 & 1.00 \\
\hline GRvi_d & 321 & 0.50 & 0.50 & 0.00 & 1.00 \\
\hline GRen1_d & 321 & 0.78 & 0.42 & 0.00 & 1.00 \\
\hline GRen2_d & 321 & 0.79 & 0.41 & 0.00 & 1.00 \\
\hline GRen3_d & 321 & 0.45 & 0.50 & 0.00 & 1.00 \\
\hline lGAbrent & 321 & 3.02 & 0.42 & 2.32 & 3.95 \\
\hline MWgdppc & 321 & 0.02 & 1.80 & 0.00 & 0.09 \\
\hline
\end{tabular}


Table A 4: Descriptive statistics of variable used in the consumers' price satisfaction analysis.

\begin{tabular}{|c|c|c|c|c|c|}
\hline Variable & Obs & Mean & Std. Dev. & Min & Max \\
\hline Price paid for electricity is fair & 57828 & 0.63 & 0.48 & 0.00 & 1.00 \\
\hline Price paid for natural gas is fair & 30811 & 0.66 & 0.47 & 0.00 & 1.00 \\
\hline Price paid for fixed telephone calls is fair & 51402 & 0.64 & 0.48 & 0.00 & 1.00 \\
\hline Female & 57828 & 0.53 & 0.50 & 0.00 & 1.00 \\
\hline 31 - 45 years & 57828 & 0.28 & 0.45 & 0.00 & 1.00 \\
\hline 46 - 60 years & 57828 & 0.25 & 0.43 & 0.00 & 1.00 \\
\hline 61 - 75 years & 57828 & 0.19 & 0.39 & 0.00 & 1.00 \\
\hline $75+$ years & 57828 & 0.05 & 0.23 & 0.00 & 1.00 \\
\hline End ed. age: 16 - 19 years & 57828 & 0.38 & 0.48 & 0.00 & 1.00 \\
\hline End ed. age: 20 + years & 57828 & 0.28 & 0.45 & 0.00 & 1.00 \\
\hline Single & 57153 & 0.21 & 0.41 & 0.00 & 1.00 \\
\hline managers & 57828 & 0.10 & 0.30 & 0.00 & 1.00 \\
\hline other white collars & 57828 & 0.11 & 0.32 & 0.00 & 1.00 \\
\hline manual workers & 57828 & 0.21 & 0.41 & 0.00 & 1.00 \\
\hline house person & 57828 & 0.12 & 0.32 & 0.00 & 1.00 \\
\hline unemployed & 57828 & 0.06 & 0.23 & 0.00 & 1.00 \\
\hline retired & 57828 & 0.24 & 0.42 & 0.00 & 1.00 \\
\hline students & 57828 & 0.08 & 0.27 & 0.00 & 1.00 \\
\hline pol. views: center & 57828 & 0.35 & 0.48 & 0.00 & 1.00 \\
\hline pol. views: right & 57828 & 0.20 & 0.40 & 0.00 & 1.00 \\
\hline pol. views: $\mathrm{dk} / \mathrm{na}$ & 57828 & 0.19 & 0.39 & 0.00 & 1.00 \\
\hline resp. coop.: avg./bad & 57828 & 0.11 & 0.31 & 0.00 & 1.00 \\
\hline Population density (a) & 57828 & 162.55 & 120.45 & 17.00 & 483.80 \\
\hline GDP at market prices (billions of euro) (a) & 57828 & 761.36 & 755.06 & 22.00 & 2321.50 \\
\hline CPI all-items annual rate of change (a) & 57828 & 2.27 & 0.96 & 0.10 & 5.30 \\
\hline Electricity yearly average price (a),(b) & 57828 & 0.14 & 0.04 & 0.06 & 0.24 \\
\hline Gas yearly average price (a),(b) & 49175 & 12.70 & 4.60 & 6.02 & 29.82 \\
\hline Year 2002 & 57828 & 0.26 & 0.44 & 0.00 & 1.00 \\
\hline Year 2004 & 57828 & 0.23 & 0.42 & 0.00 & 1.00 \\
\hline Year 2006 & 57828 & 0.25 & 0.43 & 0.00 & 1.00 \\
\hline
\end{tabular}

Source: Eurobarometer various surveys, except for (a), which come from Eurostat.

Notes: Omitted variables are: Male, 15-30 years, End education age: up to 15 years, In a couple, Self-employed, Political views: left, Respondent's cooperation: excellent/fair. (b) for electricity price is households price, with Dc tariff (Annual consumption: $3500 \mathrm{kWh}$ of which night 1300 ), including all taxes. For natural gas price is households price, with D3 tariff (year consumption: $83.70 \mathrm{GJ}$ ), including all taxes. For telecomms price is for local calls (10 minutes). 


\section{CESifo Working Paper Series}

for full list see www.cesifo-group.org/wp

(address: Poschingerstr. 5, 81679 Munich, Germany, office@cesifo.de)

3061 Ronald MacDonald and Flávio Vieira, A Panel Data Investigation of Real Exchange Rate Misalignment and Growth, May 2010

3062 Thomas Eichner and Rüdiger Pethig, Efficient Management of Insecure Fossil Fuel Imports through Taxing(!) Domestic Green Energy?, May 2010

3063 Vít Bubák, Evžen Kočenda and Filip Žikeš, Volatility Transmission in Emerging European Foreign Exchange Markets, May 2010

3064 Leonid V. Azarnert, Après nous le Déluge: Fertility and the Intensity of Struggle against Immigration, May 2010

3065 William E. Becker, William H. Greene and John J. Siegfried, Do Undergraduate Majors or Ph.D. Students Affect Faculty Size?, May 2010

3066 Johannes Becker, Strategic Trade Policy through the Tax System, May 2010

3067 Omer Biran and Françoise Forges, Core-stable Rings in Auctions with Independent Private Values, May 2010

3068 Torben M. Andersen, Why do Scandinavians Work?, May 2010

3069 Andrey Launov and Klaus Wälde, Estimating Incentive and Welfare Effects of NonStationary Unemployment Benefits, May 2010

3070 Simon Gächter, Benedikt Herrmann and Christian Thöni, Culture and Cooperation, June 2010

3071 Mehmet Bac and Eren Inci, The Old-Boy Network and the Quality of Entrepreneurs, June 2010

3072 Krisztina Molnár and Sergio Santoro, Optimal Monetary Policy when Agents are Learning, June 2010

3073 Marcel Boyer and Donatella Porrini, Optimal Liability Sharing and Court Errors: An Exploratory Analysis, June 2010

3074 Guglielmo Maria Caporale, Roman Matousek and Chris Stewart, EU Banks Rating Assignments: Is there Heterogeneity between New and Old Member Countries? June 2010

3075 Assaf Razin and Efraim Sadka, Fiscal and Migration Competition, June 2010

3076 Shafik Hebous, Martin Ruf and Alfons Weichenrieder, The Effects of Taxation on the Location Decision of Multinational Firms: M\&A vs. Greenfield Investments, June 2010 
3077 Alessandro Cigno, How to Deal with Covert Child Labour, and Give Children an Effective Education, in a Poor Developing Country: An Optimal Taxation Problem with Moral Hazard, June 2010

3078 Bruno S. Frey and Lasse Steiner, World Heritage List: Does it Make Sense?, June 2010

3079 Henning Bohn, The Economic Consequences of Rising U.S. Government Debt: Privileges at Risk, June 2010

3080 Rebeca Jiménez-Rodriguez, Amalia Morales-Zumaquero and Balázs Égert, The VARying Effect of Foreign Shocks in Central and Eastern Europe, June 2010

3081 Stephane Dees, M. Hashem Pesaran, L. Vanessa Smith and Ron P. Smith, Supply, Demand and Monetary Policy Shocks in a Multi-Country New Keynesian Model, June 2010

3082 Sara Amoroso, Peter Kort, Bertrand Melenberg, Joseph Plasmans and Mark Vancauteren, Firm Level Productivity under Imperfect Competition in Output and Labor Markets, June 2010

3083 Thomas Eichner and Rüdiger Pethig, International Carbon Emissions Trading and Strategic Incentives to Subsidize Green Energy, June 2010

3084 Henri Fraisse, Labour Disputes and the Game of Legal Representation, June 2010

3085 Andrzej Baniak and Peter Grajzl, Interjurisdictional Linkages and the Scope for Interventionist Legal Harmonization, June 2010

3086 Oliver Falck and Ludger Woessmann, School Competition and Students' Entrepreneurial Intentions: International Evidence Using Historical Catholic Roots of Private Schooling, June 2010

3087 Bernd Hayo and Stefan Voigt, Determinants of Constitutional Change: Why do Countries Change their Form of Government?, June 2010

3088 Momi Dahan and Michel Strawczynski, Fiscal Rules and Composition Bias in OECD Countries, June 2010

3089 Marcel Fratzscher and Julien Reynaud, IMF Surveillance and Financial Markets - A Political Economy Analysis, June 2010

3090 Michel Beine, Elisabetta Lodigiani and Robert Vermeulen, Remittances and Financial Openness, June 2010

3091 Sebastian Kube and Christian Traxler, The Interaction of Legal and Social Norm Enforcement, June 2010

3092 Volker Grossmann, Thomas M. Steger and Timo Trimborn, Quantifying Optimal Growth Policy, June 2010 
3093 Huw David Dixon, A Unified Framework for Using Micro-Data to Compare Dynamic Wage and Price Setting Models, June 2010

3094 Helmuth Cremer, Firouz Gahvari and Pierre Pestieau, Accidental Bequests: A Curse for the Rich and a Boon for the Poor, June 2010

3095 Frank Lichtenberg, The Contribution of Pharmaceutical Innovation to Longevity Growth in Germany and France, June 2010

3096 Simon P. Anderson, Øystein Foros and Hans Jarle Kind, Hotelling Competition with Multi-Purchasing: Time Magazine, Newsweek, or both?, June 2010

3097 Assar Lindbeck and Mats Persson, A Continuous Theory of Income Insurance, June 2010

3098 Thomas Moutos and Christos Tsitsikas, Whither Public Interest: The Case of Greece's Public Finance, June 2010

3099 Thomas Eichner and Thorsten Upmann, Labor Markets and Capital Tax Competition, June 2010

3100 Massimo Bordignon and Santino Piazza, Who do you Blame in Local Finance? An Analysis of Municipal Financing in Italy, June 2010

3101 Kyriakos C. Neanidis, Financial Dollarization and European Union Membership, June 2010

3102 Maela Giofré, Investor Protection and Foreign Stakeholders, June 2010

3103 Andrea F. Presbitero and Alberto Zazzaro, Competition and Relationship Lending: Friends or Foes?, June 2010

3104 Dan Anderberg and $\mathrm{Yu}$ Zhu, The Effect of Education on Martial Status and Partner Characteristics: Evidence from the UK, June 2010

3105 Hendrik Jürges, Eberhard Kruk and Steffen Reinhold, The Effect of Compulsory Schooling on Health - Evidence from Biomarkers, June 2010

3106 Alessandro Gambini and Alberto Zazzaro, Long-Lasting Bank Relationships and Growth of Firms, June 2010

3107 Jenny E. Ligthart and Gerard C. van der Meijden, Coordinated Tax-Tariff Reforms, Informality, and Welfare Distribution, June 2010

3108 Vilen Lipatov and Alfons Weichenrieder, Optimal Income Taxation with Tax Competition, June 2010

3109 Malte Mosel, Competition, Imitation, and R\&D Productivity in a Growth Model with Sector-Specific Patent Protection, June 2010 
3110 Balázs Égert, Catching-up and Inflation in Europe: Balassa-Samuelson, Engel's Law and other Culprits, June 2010

3111 Johannes Metzler and Ludger Woessmann, The Impact of Teacher Subject Knowledge on Student Achievement: Evidence from Within-Teacher Within-Student Variation, June 2010

3112 Leif Danziger, Uniform and Nonuniform Staggering of Wage Contracts, July 2010

3113 Wolfgang Buchholz and Wolfgang Peters, Equity as a Prerequisite for Stable Cooperation in a Public-Good Economy - The Core Revisited, July 2010

3114 Panu Poutvaara and Olli Ropponen, School Shootings and Student Performance, July 2010

3115 John Beirne, Guglielmo Maria Caporale and Nicola Spagnolo, Liquidity Risk, Credit Risk and the Overnight Interest Rate Spread: A Stochastic Volatility Modelling Approach, July 2010

3116 M. Hashem Pesaran, Predictability of Asset Returns and the Efficient Market Hypothesis, July 2010

3117 Dorothee Crayen, Christa Hainz and Christiane Ströh de Martínez, Remittances, Banking Status and the Usage of Insurance Schemes, July 2010

3118 Eric O’N. Fisher, Heckscher-Ohlin Theory when Countries have Different Technologies, July 2010

3119 Huw Dixon and Hervé Le Bihan, Generalized Taylor and Generalized Calvo Price and Wage-Setting: Micro Evidence with Macro Implications, July 2010

3120 Laszlo Goerke and Markus Pannenberg, 'Take it or Go to Court' - The Impact of Sec. 1a of the German Protection against Dismissal Act on Severance Payments -, July 2010

3121 Robert S. Chirinko and Daniel J. Wilson, Can Lower Tax Rates be Bought? Business Rent-Seeking and Tax Competition among U.S. States, July 2010

3122 Douglas Gollin and Christian Zimmermann, Global Climate Change and the Resurgence of Tropical Disease: An Economic Approach, July 2010

3123 Francesco Daveri and Maria Laura Parisi, Experience, Innovation and Productivity Empirical Evidence from Italy's Slowdown, July 2010

3124 Carlo V. Fiorio and Massimo Florio, A Fair Price for Energy? Ownership versus Market Opening in the EU15, July 2010 